GA-A15255

UC-77

\title{
LICENSING TOPICAL REPORT: INTERPRETATION OF GENERAL DESIGN CRITERIA FOR HIGH-TEMPERATURE GAS-COOLED REACTORS
}

by

D. D. ORVIS and P. H. RAABE

\author{
Prepared under \\ Contract DE-AT03-76ET35300 \\ for the San Francisco Operations Office \\ Department of Energy
}

GENERAL ATOMIC PROJECT 6400 DATE PUBLISHED: JANUARY 1980

\section{GENERAL ATOMIC COMPANY}




\section{DISCLAIMER}

This report was prepared as an account of work sponsored by an agency of the United States Government. Neither the United States Government nor any agency Thereof, nor any of their employees, makes any warranty, express or implied, or assumes any legal liability or responsibility for the accuracy, completeness, or usefulness of any information, apparatus, product, or process disclosed, or represents that its use would not infringe privately owned rights. Reference herein to any specific commercial product, process, or service by trade name, trademark, manufacturer, or otherwise does not necessarily constitute or imply its endorsement, recommendation, or favoring by the United States Government or any agency thereof. The views and opinions of authors expressed herein do not necessarily state or reflect those of the United States Government or any agency thereof. 


\section{DISCLAIMER}

Portions of this document may be illegible in electronic image products. Images are produced from the best available original document. 
•

$-$

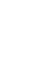


FOREWORD

This Licensing Topical Report has been prepared for submittal to the U.S. Nuclear Regulatory Commission as part of a review of issues that may bear on the licensing of commercial high-temperature gas-cooled reactors (HTGRs). More specifically, the reactors addressed herein are characterized as graphite moderated and helium cooled, with ceramic fuel in prismatic fuel elements. This review is to be conducted prior to an application for a construction permit to expedite the licensing process when an application is made and to provide a basis for licensing HTGRs on their own merit.

This report proposes General Design Criteria (GDC) for use in licensing of HTGRs based on interpretation of the GDC presented in Appendix A to Part 50, Title 10, of the Code of Federal Regulations, which were derived for light-water-cooled reactors. The GDC for HTGRs are presented as a modified text of Appendix A, which the NRC is requested to endorse as suitable for use in HTGR licensing applications. 
- 


\begin{abstract}
This Licensing Topical Report presents a set of General Design Criteria (GDC) which is proposed for applicability to licensing of graphitemoderated, high-temperature gas-cooled reactors (HTGRs). Modifications as necessary to reflect HTGR characteristics and design practices have been made to the GDC derived for applicability to light-water-cooled reactors and presented in Appendix A of Part 50, Title 10, Code of Federal Regulations, including the Introduction, Definitions, and Criteria. It is concluded that the proposed set of GDC affords a better basis for design and licensing of HTGRs.
\end{abstract}


• 
CONTENTS

FOREWORD

1. INTRODUCTION . . . . . . . . . . . . . . . . . . 1

1.1. Background . . . . . . . . . . . . . . . I

1.2. Scope . . . . . . . . . . . . . . . . . 3

1.3. Licensing objective ................ 4

1.4. Requested NRC Action... . . . . . . . . . . . . 9

2. INTERPRETATION OF GENERAL DESIGN CRITERIA FOR HTGRS:

REVISIONS TO APPENDIX A TO 1OCFR50 . . . . . . . . . . . . . . . 10

2.1. Introduction . . . . . . . . . . . . . . . . 11

2.2. Definitions and Explanations . . . . . . . . . . 16

2.2.1. Nuclear Power Unit . . . . . . . . . . 16

2.2.2. Loss-of-Coolant Accidents . . . . . . . . . 17

2.2.3. Single Failure . . . . . . . . . . . . 18

2.2.4. Anticipated Operational Occurrences . . . . . . . 19

2.2.5. Primary Coolant System Boundary . . . . . . . 20

2.2.6. Design Basis Depressurization Accidents . . . . 21

2.2.7. Accidental Ingress of Secondary or Other Fluids • 22

2.3. Criteria . . . . . . . . . . . . . . . 23

2.3.1. I. Overa11 Requirements . . . . . . . . . 23

2.3.1.1. Quality Standards and Records ..... 23

2.3.1.2. Design Bases for Protection Against Natural Phenomena . . . . . . . 24

2.3.1.3. Fire Protection .......... 25

2.3.1.4. Environmental and Missile Design Bases . . . . . . . . . . 25

2.3.1.5. Sharing of Structures, Systems, and Components . . . . . . . . . . 
2.3.2. II. Protection by Multiple Fission Product

Barriers . . . . . . . . . . . . 27

2.3.2.1. Reactor Design . . . . . . . . 27

2.3.2.2. Reactor Inherent Protection ...... 27

2.3.2.3. Suppression of Reactor Power Oscillations . . . . . . . . . 28

2.3.2.4. Instrumentation and Control . . . . 28

2.3.2.5. Primary Coolant System Boundary . . . . 29

2.3.2.6. Primary Coolant System Design . . . . 30

2.3.2.7. Containment Design . . . . . . . 30

2.3.2.8. Electric Power Systems . . . . . . 32

2.3.2.9. Inspection and Testing of Electric Power Systems . . . . . . . . 34

2.3.2.10. Control Room ............ 35

2.3.3. III. Protection and Reactivity Control Systems - 36

2.3.3.1. Protection System Functions . . . . . 36

2.3.3.2. Protection System Reliability and Testability . . . . . . . . . 37

2.3.3.3. Protection System Independence . . . . 37

2.3.3.4. Protection System Failure Modes . . . . 38

2.3.3.5. Separation of Protection and Contro1 Systems ............. 38

2.3.3.6. Protection System Requirements for Reactivity Control Malfunctions . . . 39

2.3.3.7. Reactivity Control System Redundancy and Capability........... 40

2.3.3.8. Combined Reactivity Control Systems Capability ............. 41

2.3.3.9. Reactivity Limits . . . . . . . . 42

2.3.3.10. Protection Against Anticipated Operationa1 Occurrences . . . . . . . 43

2.3.4. IV. Fluid Systems . . . . . . . . . . . . 44

2.3.4.1. Quality of Primary Coolant System Boundary .. . . . . . . . . 44

2.3.4.2. Fracture Prevention of Primary Coolant System Boundary . . . . . . . 44

2.3.4.3. Inspection of Primary Coolant System Boundary 
2.3.4.4. Reactor Coolant Makeup ........ 46

2.3.4.5. Core Auxiliary Cooling System - I . . . 47

2.3.4.6. Core Auxiliary Cooling System - II . . 49

2.3.4.7. Inspection of Core Auxiliary Cooling System . . . . . . . . 50

2.3.4.8. Testing of Core Auxiliary Cooling System . . . . . . . . . . . 50

2.3.4.9. Containment Heat Removal System . . . 51

2.3.4.10. Inspection of Containment Heat Removal System . . . . . . . 52

2.3.4.11. Testing of Containment Heat Removal System . . . . . . . . . . 52

2.3.4.12. Containment Atmosphere Cleanup . . . . 53

2.3.4.13. Inspection of Containment Atmosphere Cleanup Systems . . . . . . . . 54

2.3.4.14. Testing of Containment Atmosphere Cleanup Systems . . . . . . . . 55

2.3.4.15. Cooling Water System . . . . . . . 55

2.3.4.16. Inspection of Cooling Water System . . . 56

2.3.4.17. Testing of Cooling Water System . . . 57

2.3.4.18. Overpressure Protection of Primary Coolant System Boundary . . . . . . 57

2.3.4.19. Prestressed Concrete Reactor Vessel Liner Cooling . . . . . . . . 58

2.3.5. V. Reactor Containment . . . . . . . . 59

2.3.5.1. Containment Design Basis . . . . . 59

2.3.5.2. Fracture Prevention in Containment Structure . . . . . . . . . . 60

2.3.5.3. Capability for Testing Controlled Releases and Leakage from Containment . 62

2.3.5.4. Provisions for Containment Testing and Inspection ............ 62

2.3.5.5. Piping Systems Penetrating Containment • 63

2.3.5.6. Primary Coolant System Boundary Penetrating Containment . . . . . 64

2.3.5.7. Containment Isolation . . . . . . 65

2.3.5.8. Ćlosed System Isolation Valves . . . . 66

2.3.6. VI. Fuel and Radioactivity Control . . . . . . 67

2.3.6.1. Control of Releases of Radioactive 
2.3.6.2. Fuel Storage and Handling and Radioactivity Control........... 67

2.3.6.3. Prevention of Criticality in Fuel Storage and Handling......... 68

2.3.6.4. Monitoring Fuel and Waste Storage . . 69

2.3.6.5. Monitoring Radioactivity Releases . . 69

References . . . . . . . . . . . . . . . . 70

3. SUMMARY AND CONCLUSIONS . . . . . . . . . . . . . . . . . 71

APPENDIX: GENERAL DESIGN CRITERIA FOR HIGH-TEMPERATURE

GAS-COOLED NUCLEAR REACTOR PLANTS . . . . . . . . . A-1 


\section{INTRODUCTION}

\subsection{BACKGROUND}

Over $95 \%$ of the accumulated commercial operating experience from nuclear power plants in the United States has been contributed by watercooled reactors. Although the Peach Bottom 1 and Fort St. Vrain units represent the beginning of the application of gas-cooled reactor technology in the United States, there is a large experience base available outside the U.S., with over $40 \%$ of the commercial operating experience accumulated world-wide contributed by gas-cooled reactors. In spite of this large world-wide experience base with gas-cooled reactors, the regulations, regulatory guides, codes, and standards that have been developed in the U.S. for use in the licensing process have been directed primarily toward watercooled reactors. Although the more general portions of the regulations and supporting documents tend to be equally applicable to gas-cooled and water-cooled nuclear power plants, some of the portions address specific features of water-cooled nuclear power plants which, are not applicable to gas-cooled nuclear power plants. Still other portions of the regulatory documents have to be interpreted to clarify the intent when applied to gascooled reactors. Furthermore, there is a need to incorporate appropriate provisions in such regulations and supporting documents to address certain unique characteristics of gas-cooled nuclear power plants that are not currently addressed. This Licensing Topical Report addresses the interpretation and applicability of the General Design Criteria (GDC) set forth in Appendix A to Part 50, Title 10, of the Code of Federal Regulations (10CFR50) to graphite-moderated, high-temperature gas-cooled reactors (HTGRs). 
As noted in the Introduction to the present 10CFR50, Appendix A, "These General Design Criteria establish minimum requirements for the principal design criteria for water-cooled ${ }^{*}$ nuclear power plants . . . . The General Design Criteria are also considered to be generally applicable to other types of nuclear power units and are intended to provide guidance in establishing the principal design criteria for such other units." The final statements in that Introduction are as follows: "There may be some water-cooled nuclear power plants for which the General Design Criteria are not sufficient and for which additional criteria must be identified and satisfied . . Also, there may be water-cooled nuclear power units for which fulfillment of some of the General Design Criteria may not be necessary or appropriate. For plants such as these, departures from the General Design Criteria must be identified and justified." The intent of the above statements is clearly to provide flexibility in the GDC, even for light-water reactors. Even more flexibility is required to apply such criteria to HTGRs, and these statements serve to identify the need for this Licensing Topical Report. In this report, deletions, modifications, and additions to the GDC as set forth in the present Appendix A are proposed in recognition of the major differences between the design and operational characteristics of helium-cooled, graphite-moderated reactor plants and those of water-cooled nuclear. power units. In addition, some phraseology and definitions have been incorporated to provide additional flexibility for accommodating evolution of the regulatory requirements and process so that the criteria addressed herein may form a basis for the licensing of nuclear power plants that are to become operational in the 1990 s and beyond.

It is also realized, however, that changes are occurring in the regulatory process that cannot be accurately interpreted at this time. As a result of the Three Mile Island-2 accident and as previewed in the report of Lessons Learned Task Force, concerted efforts will be made to improve reactor safety and reliability. A prime example concerns the application

\footnotetext{
* The underscoring does not appear in the original text. It has been added here for emphasis.
} 
of the single-failure criterion. Currently, the reliability of reactor systems important to safety is evaluated through applications and interpretations of the single-failure criterion. The Lessons Learned Task Force, however, has stated that, in the long term, consideration should be given to multiple failures, including system interactive causes. For the time being, the single-failure criterion is retained in the HTGR critera proposed herein. However, any future developments in regulatory and industry practices to supplement the single-failure criterion will be incorporated as appropriate to achieve prespecified high reliability goals for HTGR safety systems.

The GDC proposed herein are generally applicable to various types of helium-cooled, graphite-moderated reactors employing ceramic fuel in prismatic fuel elements. These reactors are known as HTGRs. Where variations exist between different types of HTGR plants such as specific characteristics associated with applications in steam-cycle, direct-cycle gasturbine power conversion plants, or process-heat plants, specific interpretations of the GDC may be required in the licensing application for a specific plant.

It is noted that the main text of 10CFR50 contains certain paragraphs that specifically address light-water reactors, e.g., Section 50.46, and others that may not be entirely adequate to govern HTGRs, e.g., Section 50.55a. A logical extension of the present work would be the documentation of proposed changes to 10CFR50 so that it would adequately cover gas-cooled reactors and ensure compatibility with the GDC proposed herein. The need for formal NRC review of such material has not been evaluated at this time.

1.2. SCOPE

Section 2 of this report addresses proposed revisions to and direct applications of criteria from 10CFR50 Appendix A that could be employed to form a new appendix that more properly and completely applies to HTGR 
plants. The format of the proposed new appendix is the same as that of the present Appendix A:

1. Introduction.

2. Definitions and Explanations.

3. Criteria.

The proposed changes are summarized in Table 1-1.

As in the present Appendix A, the criteria are grouped by major category, such as Overall Requirements and Protection by Multiple Fission Product Barriers. The style of the presentation in Section 2 places emphasis in two areas: (1) the wording proposed for the new appendix to 10CFR50 in which all deletions and additions are clearly displayed, and (2) justifications for all deletions, changes in wording, and additions with respect to the present Appendix A. As a convenience to the reader, the text of the proposed new appendix is presented in the appendix to this report without intervening commentary or identification of deleted (or added) wording.

\subsection{LICENSING OBJECTIVE}

This Licensing Topical Report has two primary objectives: (1) to clarify the licensing requirements for HTGR nuclear power plants and (2) to simplify the licensing review of HTGR nuclear power plants. The first objective is addressed by presenting recommended changes to the General Design Criteria for nuclear power plants so that the regulatory intent is interpreted and rephrased in language appropriate to HTGR nuclear power plants. The second objective is achieved by providing generic documentation of those interpretations which, after NRC review and approval, can serve as a proper reference in future licensing proceedings. This will obviate the present need for case-by-case interpretation of Appendix $A$ in specific HTGR licensing applications. 
TABLE $1-1$

SUMMARY OF MODIFICATIONS AND INTERPRETATIONS OF APPENDIX A,

10CFR50 FOR HTGRs

$\underline{\text { Item }}$

Introduction

Definitions and Explanations

Nuclear power unit

Loss-of-coolant accident

Single fallure

Anticipated operational occurrence

Primary coolant system boundary

Design basis depressurization accidents

Accidental ingress of secondary or other fluids

\section{Criteria}

1. Quality standards and records

2. Design bases for protection against natural phenomena

3. Fire protection

4. Environmental and missile design bases

5. Sharing of structures, systems, and components

6-9.

10. Reactor design

11. Reactor inherent protection

12. Suppression of reactor power oscillations

13. Instrumentation and control
Summary of Changes

Change terminology; add note on possible need to use fault tree/event tree techniques in future.

Added note to include process heat applications.

Deleted.

No change in text; change footnote label.

Replace LWR examples with HTGR examples.

New.

New.

New.

No change.

No change.

No change.

Change reference to "loss of coolant" to "design basis depressurization" accident.

No change.

Criteria 6 through 9 do not appear in Appendix $A$.

No change.

No change.

No change.

Change terminology. 
TABLE 1-1 (continued)

Item

14. Primary coolant system boundary

15. Primary coolant system design

16. Containment design

17. Electric power systems

18. Inspection and testing of electric power systems

19. Control room

20. Protection system 1imits

21. Protection system reliability and testability

22. Protection system independence

23. Protection system fallure modes

24. Separation of protection and control systems

25. Protection system requirements for reactivity control malfunctions

26. Reactivity control system redundancy and capability

27. Combined reactivity control systems capability
Summary of Changes

Change title from "Reactor Coolant Pressure Boundary;" add requirement to protect against abnormal leakage of primary coolant and ingress of fluids into the primary system.

Change terminology to be consistent with 14 .

Change to provide more flexibility in design.

Change terminology to be consistent with other changes; relax requirement for backup power to be avallable "within a few seconds."

No change.

Change terminology to be consistent with other changes .

Add requirement to protect primary coolant system boundary.

No change.

No change.

No change.

No change.

Simflar to 20.

Change to recognize unique design of HTGR system and delete inference to control by dissolved boron.

Delete reference to poison additon by emergency core cooling system. 


\section{$\underline{\text { Item }}$}

28. Reactivity limits

29. Protection against anticipated operational occurrences

30. Quality of primary coolant system boundary

31. Fracture prevention of primary coolant system boundary

32. Inspection of primary coolant system boundary

33. Reactor coolant makeup

34. Core auxiliary cooling system

35. Emergency core cooling system

36. Inspection of core auxiliary cooling system

37. Testing of core auxiliary cooling system

38. Containment heat removal system

39. Inspection of containment heat removal system

40. Testing of containment heat removal system

41. Containment atmospheric cleanup

42. Inspection of containment atmospheric cleanup systems

43. Testing of containment atmospheric cleanup systems

44. Cooling water system

45. Inspection of cooling water system
Summary of Changes

Change terminology;

change 1 ist of specific accidents .

No change.

Change terminology.

Change terminology.

Change terminology; modify to be compatible with code for prestressed concrete reactor vessel components.

Deleted.

Change title; add require ments for engineered safety system for removing residual heat when main loops are not avallable.

Deleted; intent incorporated into 34 .

Change terminology to agree with 34 .

Simflar to 36 .

Deleted.

Deleted.

Deleted.

Change requirements to be compatible with HTGR.

No change.

No change.

No change.

No change. 
TABLE 1-1 (continued)

\section{Item}

46. Testing of cooling water system

47. Overpressure protection of primary coolant system boundary

48. Prestressed concrete reactor vessel liner cooling

49.

50. Containment design basis

51. Fracture prevention in containment structure

52. Capability for testing controlled releases and leakage from containment

53. Provisions for containment testing and inspection

54. Piping systems penetrating containment

55. Primary coolant system boundary penetrating containment

56. Containment isolation

57. Closed system isolation valves

58-59.

60. Control of releases of radioactive materials to the environment

61. Fuel storage and handling and radioactivity control

62. Prevention of criticality in fuel storage and handling

63. Monitoring fuel and waste storage

64. Monitoring radioactivity releases
Summary of Changes

Change terminology.

New.

New.

Criterion 49 does not appear in Appendix A.

Change terminology to be compatible with 16 .

Change to be compatible with 50 .

Change to be consistent with 16 and 50 .

Similar to 52 .

Change terminology.

Change terminology.

Change terminology.

Change terminology.

Criteria 58-59 do not appear in Appendix $A$.

No change.

No change.

No change.

No change.

Delete reference to recirin loss-of-coolant accident. 


\subsection{REQUESTED NRC ACTION}

The Nuclear Regulatory Commission (NRC) Staff is requested to review the proposed criteria and justifications submitted in Section 2 of this report and to develop formal comments on the content of this Licensing Topical Report. Subsequent to satisfactory resolution of such comments and incorporation of any required amendments into the report, the Staff is requested to provide written approval that the proposed GDC adequately account for the characteristics of HTGR reactor plants and, as an appropriate interpretation of 10CFR50 Appendix A, are sufficient to govern the design of such a plant.

Although not a part of the present requested action, incorporation of the proposed GDC for HTGRs as a new appendix to 10CFR50 may be appropriate in the future. 


\section{INTERPRETATION OF GENERAL DESIGN CRITERIA FOR HTGRS: REVISIONS TO APPENDIX A TO 1OCFR50}

Although Appendix A to 10CFR50 provides a set of GDC that are intended to provide general guidance for applications of a11 types of nuclear power units, it was developed to establish minimum requirements for water-cooled nuclear units. This section develops modified wording of Appendix A to provide appropriate interpretation and application to graphite-moderated, high-temperature gas-cooled reactors (HTGRs).

Since the modified text, after appropriate reviews and rule making, may be incorporated as a new appendix to 10CFR50 at some future time, the format of the proposed GDC for gas-cooled nuclear power units is basically the same as that of the present Appendix A. The three major sections are Introduction, Definitions, and Criteria. The third section presents the actual GDC, grouped under general headings such as Overall Requirements, Protection by Multiple Fission Product Barriers, etc., retaining the headings of Appendix A. The material that follows presents the proposed new appendix in the following format: the wording proposed for a particular portion of the appendix (the Introduction, the Definitions, or an individual criterion), followed by a justification for all deletions, changes, and additions with respect to the present Appendix A, and, as appropriate, an indication of the manner in which the intent of the present wording of Appendix $\mathrm{A}$ has been preserved for gas-cooled nuclear power units. The entire text of the proposed GDC for gas-cooled nuclear power units is presented with no intervening commentary in the appendix to this report. 


\subsection{INTRODUCTION}

a. Statement of Text

Pursuant to the provisions of Para 50.34, an application for a construction permit must include the principal design criteria for a proposed facility. The principal design criteria establish the necessary design, fabrication, construction, testing, and performance requirements for structures, systems, and components important to safety; that is, structures, systems, and components that provide reasonable assurance that the facility can be operated without undue risk to the health and safety of the public.

These General Design Criteria establish minimum requirements for the principal design for [water-eoołed]* graphite-moderated, high-temperature gas-cooled ${ }^{* * *}$ nuclear power plants similar in design and location to plants [for-whieh construetion-permits-have-been-issued] for which an operating

license has been issued or licensing applications have been previously docketed by the Commission. The General Design Criteria are also considered to be generally applicable to other types of gas-cooled thermal-reactor nuclear power units such as those employing a direct-cycle gas turbine or those employed to produce process heat and are intended to provide guidance in establishing the principal design criteria for such other units.

\footnotetext{
* Text enclosed in brackets and ruled out (that is, with hyphens overlaid on top of the individual letters) identifies portions of text of the present Appendix A to be deleted.

** Numbers in the right margin identify changes for referencing convenience in the sections entitled Justifications.

${ }^{* \star *}$ Text that is underscored identifies additions to the text of the present Appendix A.
} 
The development of these General Design Criteria is not yet complete. For example, some of the definitions need further amplification. Also, some of the specific design requirements for structures, systems, and components important to safety have not as yet been suitably defined. Their omission does not relieve any applicant from considering these matters in the design of a specific facility and satisfying the necessary safety requirements. These matters include:

(1) Consideration of the need to design against single failures of passive components in fluid systems important to safety. (See Definition of Single Failure.)

(2) Consideration of redundancy and diversity requirements for fluid systems important to safety. A "system" could consist of a number of subsystems each of which is separately capable of performing the specified system safety function. The minimum acceptable redundancy and diversity of subsystems and components within a subsystem, and the required interconnection and independence of the subsystems have not yet been developed or defined. (See Criteria 34, [35,-38] 41, and 44.)

(3) Consideration of the type, size, and orientation of possible breaks in components of the [reactor-eoolant-pressure boundary] primary coolant system boundary in determining design requirements to suitably protect against postulated [łoss-of 9 cootant-aceidents] design basis depressurization accidents and 10 ingress of secondary or other fluids into the primary system. 11 (See Definitions of [Eoss-of-Eootant-Aceidents] Design Basis 12 Depressurization Accidents and Ingress of Secondary or Other F1uids.) 
(4) Consideration of the possibility of systematic, nonrandom, concurrent failures of redundant elements in the design of protection systems and reactivity control systems. (See Criteria 22, 24, 26, and 29.)

(5) Consideration of factors that affect the avai1ability of systems important to safety to perform their safety functions when called upon, for example, through the use of reliability assessment techniques such as fault trees and event trees.

It is expected that the criteria will be augmented and changed from time to time as important new requirements for these and other features are developed.

There will be some [water-eooted] high-temperature gascooled nuclear plants for which the General Design Criteria are not sufficient and for which additional criteria must be identified and satisfied in the interest of public safety. In particular, it is [expeeted] possible that additional or different 18,19 criteria [wiłt] may be needed to take into account unusual 20,21 sites and environmental conditions and to provide for [water 22,23 cooted] high-temperature gas-cooled nuclear power units of 24 advanced design. Also, there may be [water-eooted] high25,26 temperature gas-cooled nuclear power units for which fulfillment of some of the General Design Criteria may not be necessary or appropriate. For plants such as these, departures from the General Design Criteria must be identified and justified.

\section{b. Justification}

The first paragraph is included with no change in wording from that in the present Appendix A because of its broad generality. 
In the second paragraph, changes 1 and 2 are necessary to change applicability from water-cooled to graphite-moderated, high-temperature gas-cooled nuclear power plants (HTGRs). In the case of changes 3 and 4 , it is recognized that a difference exists in the experience bases accumulated from the NRC's licensing of water-cooled and gas-cooled nuclear power plants. The changes permit the inclusion of the licensing experience gained from more recent designs of HTGRs (based on the docketed Fulton and Summit plants), together with an earlier design (Fort St. Vrain plant) for which an operating license has been issued by the Commission. Changes 5 and 6 have been included to further clarify the breadth of applicability of the General Design Criteria.

The third paragraph and its subparagraphs numbered (1) and (4) are of sufficient generality as to require no change. However, subparagraphs (2) and (3) have been modified and a new subparagraph (5) has been added. Change 7 reflects the deletion of Criteria 35 and 38 . Changes 8 and 9 merely reflect the use of the appropriate terminology as it has evolved for gas-cooled nuclear power plants and do not in any way alter the intent as expressed in the present Appendix A. The specific wording change is the same as that recommended in Ref. $2-1 . *$

Changes 10 and 11 are made to reflect appropriate design features of the HTGR. It is clear that the intent of the present Appendix A in subparagraph (3) is to address the effects of a possible break in the physical boundary that contains the fluid that passes through and cools the reactor core in a nuclear power unit. In the case of water-cooled nuclear power units, ruptures can occur in major piping connecting the components in the reactor coolant system. The effect of such ruptures is a loss of a substantial portion of the cooling water, as well as phase changes and changes in the heat transfer characteristics of the coolant. This condition is known as a loss-of-coolant accident. To accommodate such loss-of-coolant accidents, an emergency core cooling system is required (in water-cooled nuclear power units) that can provide sufficient

\footnotetext{
${ }^{*}$ References are listed at the end of Section 2 .
} 
cooling within a short time frame to prevent unacceptable damage to the reactor core. However, in the case of gas-cooled nuclear power units, hardware fallures of the type identified above can lead to different types of effects, depending on failure location. One class of failure can lead to a reduction in primary coolant pressure. However, this type of depressurization event does not lead to a loss of the ability of the gaseous primary coolant to flow through and adequately cool the reactor core nor to a change in phase of the primary coolant. In such situtations, core cooling can be maintained (without the need for supplemental or replacement cooling from a backup or emergency system) as long as the primary coolant can be circulated through the reactor core (by forced circulation or by natural convection) and as long as heat can be removed from the circulating primary coolant. These situations that involve a reduction in pressure of the primary coolant and that have come to be regarded as a counterpart to loss-of-coolant accidents in water-cooled nuclear power units are appropriately known as design basis depressurization accidents* and are defined in Section 2.2.6.

Another class of failure or breach of the primary coolant system boundary can lead to the ingress of secondary or other fluids into the primary coolant system. Such fluids might be lubricants for bearings of circulators, secondary system coolants, or other fluids that must be identified for a particular HTGR design. The ingress of such fluids can lead to conditions that may induce oxidation of exposed surfaces of the core and its support structure, the generation of potentially flammable gases, and a possible increase in the pressure of the primary coolant. These events are defined in Section 2.2.7. Change 12 simply accommodates an increase in the number of defined terms cited, and changes 13 and 14 identify the two terms referenced in the Definitions section.

\footnotetext{
* There are lesser depressurization events in gas-cooled nuclear power units just as there are lesser coolant-loss events in water-cooled nuclear power units. The design basis depressurization accidents and loss-of-coolant accidents represent limiting design conditions used in the licensing process for the respective types of nuclear power units.
} 
Change 15 adds a new subparagraph which acknowledges that the developing methodology for reliability analysis should be considered in assessing the design adequacy of systems important to safety. While no specific design criteria in this area have been established for either HTGRs or LWRs, it is expected that these will, in time, be developed. As appropriate, and as noted in the fourth paragraph of the text, it is expected that the General Design Criteria for HTGRs will be modified as these and other features are developed.

The fourth paragraph is identical to that in Appendix A.

In the last paragraph, changes 16,17 , and 18 through 26 are needed to change applicability from water-cooled to high-temperature gas-cooled nuclear power plants. The reason for changes 18 through 21 is that siting and environmental considerations are not expected to necessitate additional or different criteria in the case of HTGR nuclear power units because of the excellent safety characteristics as assessed numerically in Ref. 2-2. However, it is recognized that a need for such changes in the criteria is possible. Change 22 has been made in an effort to improve clarity.

\subsection{DEFINITIONS AND EXPLANATIONS}

\subsubsection{Nuclear Power Unit}

\section{a. Statement of Text}

Nuclear power unit. A nuclear power unit means a nuclear power reactor and associated equipment necessary for electric power generation or for supplying heat for industrial processes and includes those structures, systems, and components required to provide reasonable assurance the facility can be operated without undue risk to the health and safety of the public. 
b. Justification

Change 27 is made to account for proposed applications of HTGRs as heat sources for industrial processes as well as for generating electricity.

\subsubsection{Loss-of-Coolant Accidents}

a. Statement of Text

[ boss-of-eootant-aecidents---Eoss-of-eoołant-aceidents

meens-those-postułated-aeeidents-that-resttt-from-the-toss-of

reactor-cootant-at-a-rate-in-excess-of-the-eapabittty-of-the

reactor-coołant-makeup-system-from-breaks-in-the-reactor

eoołant-pressure-boundary5-up-to-and-inetuding-a-break-equiva-

tent-in-size-to-the-doubte-ended-rupture-of-the-łargest-pipe-of

the-reator-eootant-system ${ }^{1}$ ]

[This includes the following footnote.]

[ $1_{\text {Further-detaiłs-rełating-to-the-type;-size;-and }}$

ortentation-of-postulated-breaks-in-speetfite-eomponents-of-the

reactor-eootant-pressure-boundary-are-under-devełopmentr ]

b. Justification

As discussed in detail in Section 2.1, the term "loss-of-coolant accident" and the associated accident concept are not applicable to gascooled nuclear power units. Hence, the deletions identified by changes 28 and 29 are appropriate. Accidents that involve breach of the primary coolant system boundary for the HTGR are defined in Sections 2.2.6 and 2.2 .7 . 


\subsubsection{Single Failure}

a. Statement of Text

Single failure. A single failure means an occurrence which results in the loss of capability of a component to perform its intended safety functions. Multiple failures resulting from a single occurrence are considered to be a single failure. Fluid and electric systems are considered to be designed against an assumed single failure if neither (1) a single failure of any active component (assuming passive components function proper1y) nor (2) a single failure of a passive component (assuming acitve components function properly), results in a loss of the capability of the system to perform its safety functions. $[z]^{1}$

[The following footnote is included.]

$[z]^{l}$ Single failures of passive components in electric systems should 32,33 be assumed in designing against a single failure. The conditions under which a single failure of a passive component in a fluid system should be considered in designing the system against a single failure are under development.

\section{b. Justification}

The wording is identical to that in Appendix A because it is sufficiently general to be applicable to the HTGR. The reliability and performance requirements for systems important to safety are currently based on application and interpretation of the single-failure criterion using the above definition. It is noted, however, that it is stated in NUREG-0578, "TMI-2 Lessons Learned Task Force: Status Report and ShortTerm Recommendations," that, in the long term, the single-failure criterion 
may be supplemented by considerations of multiple failures. As appropriate, any supplements to the single-failure criterion which are established through revisions to 10CFR50 Appendix A will be incorporated into the General Design Criteria for HTGRs.

Changes 30 through 33 reflect the deletion of footnote number 1 of Appendix A in Section 2.2.2.

\subsubsection{Anticipated Operational Occurrences}

\section{a. Statement of Text}

Anticipated operational occurrences. Anticipated operational occurrences mean those conditions of normal operation which are expected to occur one or more times during the life of the nuclear power unit and include but are not limited to [Zoss-of-power-to atz-reeireutation-pumps] tripping of a helium circulator, helium circulator runup, tripping of the [the] a turbine generator set, isolation of the main condenser, and loss of all offsite power.

b. Justification

The deletion identified as change 34 is appropriate because gascooled nuclear power units have no recirculation pumps. Change 35 adds operational considerations involving helium circulators, which are unique to gas-cooled nuclear power units. Changes 36 and 37 reflect the potential for having more than one turbine generator set at a nuclear power unit, as in some designs currently under consideration, particularlly for HTGR plants employing direct-cycle gas turbines. 
2.2.5. Primary Coolant System Boundary

a. Statement of Text

Primary coolant system boundary. Primary coolant means

the helium gas that flows through and transports heat away from

the reactor core. Primary coolant system boundary means the physical structure that contains the primary coolant. For hightemperature gas-cooled reactors, the primary coolant system boundary consists of (1) the liner of the prestressed concrete reactor vessel (PCRV) including cavity and penetration liners which are exposed to primary coolant, in conjuction with the prestressed concrete structure, (2) primary closures that seal penetrations in the liner of the PCRV, (3) system piping that contains primary coolant and penetrates the PCRV liner or closures up to and including the second isolation valve, (4) the PCRV overpressure protection system up to and including pressure relief valves that vent to the containment, (5) system piping within the PCRV, such as heat exchanger tubing, that is exposed to primary coolant unless the boundary is provided externa1 to the PCRV, and (6) primary coolant retaining parts of mechanical components such as seals on shafts of helium circulators or gas-turbines within the primary coolant system. In specific adaptations of the HTGR, it may be necessary to augment or modify this definition of primary coolant system boundary to properly address certain design features.

b. Justification

Change 38 is an addition to the Definitions and Explanations section of Appendix A to explicitly define the primary coolant system boundary for the HTGR, which is the term introduced into the criteria contained in this report, and which is somewhat different than the reactor coolant pressure boundary of light-water reactors. The latter is defined in 10CFR50.2(v) and is, therefore, not included in the definition of Appendix A. 
Many portions of the HTGR primary coolant system boundary can be considered equivalent to the reactor coolant pressure boundary of LWRs. These portions, by and large, are designed to the same industry codes as the LWR counterparts. For example, the penetrations and closures of the PCRV are pressure-retaining boundaries and are designed to ASME Section III, Division 1, Code requirements, as are LWR pressure vessels. However, a large portion of the HTGR primary coolant system boundary is the PCRV liner. The liner, by itself, is not considered to be a pressure-retaining component although it is a gas boundary. Pressure retention is accomplished by the prestressed concrete structure which backs the liner. The liner is designed to ASME Section III, Division 2, Code requirements.

The definition presented above is intended to be generally applicable to all graphite-moderated HTGRs which employ a PCRV. It is anticipated that application of the definition (e.g., to determine the points in a system where changes of equipment safety classification should occur) may require interpretation for a given HTGR configuration.

\subsubsection{Design Basis Depressurization Accidents}

a. Statement of Text

Design basis depressurization accidents. Design basis depressurization accidents mean those postulated accidents in which a rapid reduction in primary coolant pressure occurs as a result of egress of a portion of the primary coolant system inventory from a breach of the primary coolant system boundary up to a maximum credible flow area, e.g., a postulated failure of mechanical seals of rotating shafts which penetrate the primary coolant system boundary, or a postulated failure of the largest pipe, external to the PCRV, that is part of the primary coolant system boundary. 
b. Justification

In accord with the discussion in Section 2.1 , this definition (identified as change 39) replaces the light-water reactor design basis loss-of-coolant accident, which is shown to be deleted in Section 2.2.2. The basic justification for the wording shown above can be found in Section $2 \cdot 1 \cdot \mathrm{b}$.

It should be noted that the above definition does not explicitly quantify the magnitude of the breach to be associated with the design basis depressurization accident but allows flexibility in its application on a case-by-case basis.

\subsubsection{Accidental Ingress of Secondary or Other Fluids}

a. Statement of Text

Accidental ingress of secondary or other fluids. An accidental ingress of secondary or other fluids is an event wherein a fluid such as water, steam, or other nonprimary fluid is inadvertently admitted to the primary coolant system.

\section{b. Justification}

Change 40 accounts for events that are not unique to gas-cooled reactors but are potentially more severe for gas-cooled reactors than they would be for water-cooled reactors. Normally, the primary coolant is essentially inert with controlled levels of oxidants and erosion agents. However, the ingress of significant quantities of nonprimary fluids can lead to oxidation and erosion of fuel, core support components, and other structural components; possible production of flammable gases; degradation of the insulating quality of PCRV thermal barriers; possible overpressurization of the primary coolant system; and potential reactivity insertion by ingress of neutron moderators. The wording of the definition is meant to be general enough to cover events that might occur with the various 
types of HTGRs. Whereas a class of accident known as moisture ingress (or water ingress) has been designated as a design basis accident and evaluated in the safety analysis reports of steam-cycle HTGRs, it is believed that design features of some HTGR plants, such as the direction of the pressure differential between primary and secondary systems, may eliminate moisture ingress per se as a design basis event. However, there remains the potential for accidental admission of lubricants or seal auxiliary fluids from the shaft bearings and seals of the helium circulators or the turbomachine in the case of the direct-cycle gas turbine configuration. Where credible sources of ingress of nonprimary fluids exist, the consequences must be evaluated for their potential impact on the integrity of the plant and the health and safety of the public.

\subsection{CRITERIA}

2.3.1. I. Overall Requirements

2.3.1.1. Quality Standards and Records

a. Statement of Text

Criterion 1 - Quality standards and records. Structures, systems, and components important to safety shall be designed, fabricated, erected, and tested to quality standards commensurate with the importance of the safety functions to be performed. Where generally recognized codes and standards are used, they shall be identified and evaluated to determine their applicability, adequacy, and sufficiency and shall be supplemented or modified as necessary to assure a quality product in keeping with the required safety function. A quality assurance program shall be established and implemented in order to provide adequate assurance that these structures, systems, and components will satisfctorily perform their safety functions. Appropriate records of the design, fabrication, erection, and testing of structures, systems, and components important to 
safety shall be maintained by or under the control of the nuclear power unit licensee throughout the life of the unit.

b. Justification

No change is recommended because the Appendix A criterion is sufficiently general to apply to HTGRs.

2.3.1.2. Design Bases for Protection Against Natural Phenomena

a. Statement of Text

Criterion 2 - Design bases for protection against natural phenomena. Structures, systems, and components important to safety shall be designed to withstand the effects of natural phenomena such as earthquakes, tornadoes, hurricanes, floods, tsunami, and seiches without loss of capability to perform their safety functions. The design bases for these structures, systems, and components shall reflect: (1) Appropriate consideration of the most severe of the natural phenomena that have been historically reported for the site and surrounding area, with sufficient margin for the limited accuracy, quantity, and period of time in which the historical data have been accumulated; (2) appropriate combinations of the effects of normal and accident conditions with the effects of the natural phenomena and (3) the importance of the safety functions to be performed.

b. Justification

No change is recommended because the Appendix A criterion is sufficlently general to apply to HTGRs. 


\subsubsection{Fire Protection}

a. Statement of Text

Criterion 3 - Fire protection. Structures, systems, and components important to safety shall be designed and located to minimize, consistent with other safety requirements, the probability and effect of fires and explosions. Noncombustible and heat resistant materials shall be used wherever practical throughout the unit, particulary in locations such as the containment and control room. Fire detection and fighting systems of appropriate capacity and capability shall be provided and designed to minimize the adverse effects of fires on structures, systems, and components important to safety. Firefighting systems shall be designed to assure that their rupture or inadvertent operation does not significantly impair the safety capability of these structures, systems, and components.

\section{b. Justification}

No change is recommended since the Appendix A criterion is sufficiently general to apply to HTGRs.

\subsubsection{Environmental and Missile Design Bases}

\section{a. Statement of Text}

Criterion 4 - Environmental and missile design bases. Structures, systems, and components important to safety shall be designed to accommodate the effects of and to be compatible with the environmental conditions associated with normal operation, maintenance, testing, and postulated accidents, including 
[Zoss-of-cootant-aceidents] design basis depressurization

accidents. These structures, systems, and components shall be appropriately protected against dynamic effects, including the effects of missiles, pipe whipping, and discharging fluids, that may result from equipment failures and from events and conditions outside the nuclear power unit.

\section{b. Justification}

Changes $4 \mathrm{a}$ and $4 \mathrm{~b}$ introduce appropriate terminology as described in Sections $2.1,2.2 .2$, and 2.2.6.

\subsubsection{Sharing of Structures, Systems, and Components}

a. Statement of Text

Criterion 5 - Sharing of structures, systems, and components. Structures, systems, and components important to safety shall not be shared among nuclear power units unless it can be shown that such sharing will not significantly impair their ability to perform their safety functions, including, in the event of an accident in one unit, an orderly shutdown and cooldown of the remaining units.

b. Justification

No change is recommended because the Appendix A criterion is sufficiently general to apply to HTGRs.

${ }^{*}$ In this section, change numbers consist of a preface corresponding to the criterion number followed by a sequential letter. 
2.3.2. II. Protection by Multiple Fission Product Barriers

\subsubsection{Reactor Design}

a. Statement of Text

Criterion 10 - Reactor design. The reactor core and associated coolant, contro1, and protection systems shall be designed with appropriate margin to assure that specified acceptable fuel design limits are not exceeded during any condition of normal operation, including the effects of anticipated operational occurrences.

b. Justification

No change is recommended because the Appendix A criterion is sufficiently general to apply to HTGRs.

\subsubsection{Reactor Inherent Protection}

a. Statement of Text

Criterion 11 - Reactor inherent protection. The reactor core and associated coolant systems shall be designed so that in the power operating range the net effect of the prompt inherent nuclear feedback characteristics tends to compensate for a rapid increase in reactivity.

b. Justification

No change is recommended because the Appendix A criterion is sufficiently general to apply to HTGRs. 


\subsubsection{Suppression of Reactor Power Oscillations}

a. Statement of Text

Criterion 12 - Suppression of reactor power oscillations. The reactor core and associated coolant, control, and protection systems shall be designed to assure that power oscillations which can result in conditions exceeding specified acceptable fuel design limits are not possible or can be reliably and readily detected and suppressed.

\section{b. Justification}

No change is recommended because the Appendix A criterion is sufficiently general to apply to HTGRs.

\subsubsection{Instrumentation and Control}

a. Statement of Text

Criterion 13 - Instrumentation and control. Instrumentation shall be provided to monitor variables and systems over their anticipated ranges for normal operation, for anticipated operational occurrences, and for accident conditions as appropriate to assure adequate safety, including those variables and systems that can affect the fission process, the integrity of the reactor core, the [reaetor-eootant-pressure] primary coolant system boundary, and the containment and its associated systems. Appropriate controls shall be provided to maintain these variables and systems within prescribed operating ranges.

\section{b. Justification}

Changes $13 \mathrm{a}$ and $13 \mathrm{~b}$ are made to employ HTGR terminology defined in Section 2.2.5. 


\subsubsection{Primary Coolant System Boundary}

a. Statement of Text

Criterion 14 - [Reactor-eootant-pressure] Primary coolant

$14 \mathrm{a}, 14 \mathrm{~b}$

system boundary. The [reactor-eootant-pressure] primary

$14 \mathrm{c}, 14 \mathrm{~d}$

coolant system boundary shall be designed, fabricated, erected, and tested so as to have an extremely low probability [of

abnormat-łeakage-; of rapidly propagating failure, [and] of

gross rupture, and of abnormal leakage of (1) primary coolant

to a secondary coolant or auxiliary coolant system, to the containment, or to the environment, and (2) secondary coolant or other fluids to the primary coolant system.

\section{b. Justification}

Although the Appendix A Criterion 14 is sufficiently general to apply to gas-cooled reactors, it is proposed to expand it to reflect concerns for the integrity of the primary coolant system boundary for the gas-cooled, graphite-moderated reactors as well as to use accepted HTGR terminology. Changes $14 \mathrm{a}$ through $14 \mathrm{~d}$ merely change the terminology to be consistent with the definition of Section 2.2.5. Changes $14 \mathrm{e}$ and $14 \mathrm{f}$ reorder the sequence of concerns. Change $14 \mathrm{~g}$ expands the concern about abnormal leakage to be more specific. The first part states explicitly what types of primary coolant leakage are to be guarded against. The second part expresses the need to prevent contamination of the primary coolant, which generally is inert with respect to reactions with fuel, reactor internals, and primary system components. Such contaminants may contain oxidants, other corrosives, or possibly neutron moderators. There is the possibility of oxidation or other chemical reaction with fuel blocks, core support, or fuel particles; pressure buildup or the creation of flammable gases in the primary system; or potential reactivity insertion by nonprimary fluids. 
2.3.2.6. Primary Coolant System Design

a. Statement of Text

Criterion 15 - [Reaetor] Primary coolant system design. 15a,15b

The [reaetor] primary coolant system and associated auxiliary, 15c,15d

control, and protection systems shall be designed with

sufficient margin to assure that the design conditions of the

[reactor-cootant-pressure] primary coolant system boundary are

not exceeded during any condition of normal operation,

including anticipated operational occurrences.

b. Justification

Changes $15 \mathrm{a}$ through $15 \mathrm{f}$ are made to incorporate appropriate

terminology for the HTGR that has come into accepted usage as defined in Section 2.2.5.

2.3.2.7. Containment Design

a. Statement of Text

Criterion 16 - Containment design. Reactor containment and associated systems shall be provided to establish [an

$16 a$

essentiatyy-łeak-tight] a barrier against the uncontrolled release of radioactivity to the environment and to assure that the containment design conditions important to safety are not exceeded for as long as postulated accident conditions require. Containment design conditions important to safety include the siting criteria in Part 100 of Title 10 of the Code of Federal Regulations. During normal operating conditions, the containment and associated plant systems shall meet the release criteria in Appendix I to Part 50 of Title 10 of the Code of Federal Regulations. 


\section{b. Justification}

Changes $16 \mathrm{a}$ through $16 \mathrm{c}$ are introduced to provide greater flexibility in the design criteria for containment while meeting the intent of protecting public health and safety. While the goal of this report is to develop General Design Criteria for HTGRs, the proposed modifications to Criterion 16 may be applicable to all reactor types.

It is clear that the primary intent of the General Design Criteria with respect to containment is to provide for a barrier against the uncontrolled release of fission products to the external environment that can mitigate the consequences of credible accidents to the extent that the effects do not pose undue risk to the health and safety of the public. This is generally interpreted as remaining within siting guidelines set forth in Part 100 of Title 10 of the Code of Federal Regulations. In addition, the containment serves to control routine releases of radioactivity to the environment, as stipulated by Criterion 60 . Since the potential effects on public health and safety depend on the size and type of nuclear power plant and on the specific site selected for its operation, it follows that the requirements for restricting fission product releases to satisfy siting and environmental guidelines can vary from one application to another.

However, Criterion 16 of Appendix A requires that an "essentially leak-tight" barrier be used in all applications irrespective of reactor type, power level, or inherent characteristics. Since the determination of what is "essentially" leak-tight is subject to judgment and interpretation (such as Appendix $J$ to 10CFR50), it would be preferable to have a quantitative criterion to determine containment adequacy. It is reasonable to allow some degree of flexibility in selecting the type of containment system to be used, providing that the selected containment can control and limit radioactive releases from design basis events to a level compatible with those quantitative requirements. Currently, the applicable guidelines are given in Part 100 and Appendix $I$ to Part 50 of the Code of Federal Regulations. It is noted that a precedent was established 
for the HTGR by the Fort St. Vrain plant, which employs a vented reactor building, by taking credit for fission product retention features of its prestressed concrete reactor vessel and the characteristics of fission product release from the ceramic fuel and graphite.

Furthermore, there are other reasons for deviating from the leaktight requirement. The first item in the list of recommended research projects in the NRC report to the Congress on research to improve safety of light-water reactor plants (Ref. 2-3) is "Alternate containment concepts, especially vented containments." This appears to be consistent with the recommendations of the American Physical Society on 1ight-water reactor safety (Ref. 2-4). Such proposals recognize that a containment system that affords a controlled release of radioactivity not exceeding a known amount may be preferable to a presumed leak-tight system that may fail in certain accident sequences, even if such sequences are not generally considered to be design basis events.

In summary, Changes 16 a through $16 \mathrm{c}$ introduce flexibility which may be applicable to all reactor types.

\subsubsection{Electric Power Systems}

a. Statement of Text

Criterion 17 - Electric power systems. An onsite electric power system and an offsite electric power system shall be provided to permit functioning of structures, systems, and components important to safety. The safety function for each system (assuming the other system is not functioning) shall be to provide sufficient capacity and capability to assure that (1) specified acceptable fuel design limits and design conditions of the [reactor-cootant-pressure] primary coolant system boundary are not exceeded as a result of anticipated operational occurrences and (2) the core is cooled and containment integrity and other vital functions are maintained in the event of postulated accidents. 
The onsite electric power supplies, including the batteries, and the onsite electric distribution system, shall have sufficient independence, redundancy, and testability to perform their safety functions assuming a single failure.

Electric power from the transmission network to the onsite electric distribution system shall be supplied by two physically independent circuits (not necessarily on separate rights of way) designed and located so as to minimize to the extent practical the likelihood of their simultaneous failure under operating and postulated accident and environmental conditions. A switchyard common to both circuits is acceptable. Each of these circuits shall be designed to be available in sufficient time following a loss of all onsite alternating current power supplies and the other offsite electric power circuit, to assure that specified acceptable fuel design limits and design conditions of the [reactor-eootant-pressure] primary coolant system boundary are not exceeded. One of these circuits shall be designed to be available [within-a-few seconds] in sufficient time following a [łoss-of-cootant aceident] design basis depressurization accident to assure that core cooling, containment integrity, and other vital safety functions are maintained.

Provisions shall be included to minimize the probability of losing electric power from any of the remaining supplies as a result of, or coincident with, the loss of power generated by the nuclear power unit, the loss of power from the transmission network, or the loss of power from the onsite electric power supplies . 
b. Justification

Changes 17 a through $17 \mathrm{~d}$ account for a change in terminology, as discussed in Sections 2.2 .5 and 2.3.2.6. The justification for changes $17 \mathrm{~g}$ and $17 \mathrm{~h}$ is given in Section $2.1 . \mathrm{b}$. and is consistent with Section 2.2.6. Changes $17 \mathrm{e}$ and $17 \mathrm{f}$ reflect the difference between the thermal inertias of a water-cooled reactor core and an HTGR graphite-moderated core. In the case of light-water cooled reactors that employ metal-clad fuel rods and metallic fuel assemblies, the heat capacity of the core is relatively small. As a result, a postulated loss-of-coolant accident requires a short response time (of the order of seconds) to supply emergency core cooling water to avert a potential core-melt accident. This time scale is stated in Criterion 17 of Appendix A. However, in the case of HTGRs, the heat capacity of the core is very large because of the large mass of the graphite core structure. As a result, the assumed startup time for the core auxiliary cooling system is a matter of minutes following a postulated design basis depressurization accident. In fact, the graphite core can tolerate a slow response time (of the order of hours) before core cooling is needed to avert a core heatup and consequent release of any major portion of the fission product inventory of the core. Hence, changes $17 \mathrm{e}$ and $17 \mathrm{f}$ maintain the intent of having auxiliary power available "in sufficient time" without overspecifying the criterion or being unnecessarily restrictive.

\subsubsection{Inspection and Testing of Electric Power Systems}

a. Statement of Text

Criterion 18 - Inspection and testing of electric power systems. Electric power systems important to safety shall be designed to permit appropriate periodic inspection and testing of important areas and features, such as wiring, insulation, connections, and switchboards, to assess the continuity of the systems and the condition of their components. The systems 
sha11 be designed with a capability to test periodically (1) the operability and functional performance of the components of the systems, such as onsite power sources, relays, switches, and buses, and (2) the operability of the systems as a whole and, under conditions as close to design as practical, the full operation sequence that brings the systems into operation, including operation of applicable portions of the protection system, and the transfer of power among the nuclear power unit, the offsite power system, and the onsite power system.

\section{b. Justification}

No change is recommended because the Appendix A criterion is sufficiently general to apply to HTGRs.

\subsubsection{Control Room}

\section{a. Statement of Text}

Criterion 19 - Control room. A control room shall be provided from which actions can be taken to operate the nuclear power unit safely under normal conditions and to maintain it in a safe condition under accident conditions, including [Zess-of coołant-aceidents] design basis depressurization accidents. Adequate radiation protection shall be provided to permit access and occupancy of the control room under accident conditions without personnel receiving radiation exposures in excess of 5 rem whole body, or its equivalent to any part of the body, for the duration of the accident.

Equipment at appropriate locations outside the control room shall be provided (1) with a design capability for prompt hot shutdown of the reactor, including necessary instrumentation and controls to maintain the unit in a safe condition during hot shutdown, and (2) with a potential capability for 
subsequent cold shutdown of the reactor through the use of suitable procedures.

b. Justification

Changes $19 \mathrm{a}$ and $19 \mathrm{~b}$ introduce appropriate terminology as defined in Sections 2.1. and 2.2.2.

\subsubsection{Protection and Reactivity Control Systems}

\subsubsection{Protection System Functions}

a. Statement of Text

Criterion 20 - Protection system functions. The protection system shall be designed (1) to initiate automatically the operation of appropriate systems including the reactivity control systems to assure that specified acceptable [fuez design-timits] design 1imits for the fuel and primary coolant system boundary are not exceeded as a result of anticipated operational occurrences and (2) to sense accident conditions and to initiate the operation of systems and components important to safety.

\section{b. Justification}

By and large, the Appendix A criterion is sufficiently general that is is essentially applicable to gas-cooled reactors. However, changes 20a and $20 \mathrm{~b}$ are made to reflect the fact that fuel design limits are generally not the most limiting for reactors of the HTGR type because of the use of coated ceramic fuel and high heat capacity core, but limits on components associated with the primary coolant system boundary, especially metallic components, may be controlling. Since the reactor protection system should act to maintain the integrity of multiple fission product barriers, it is appropriate to include this requirement in Criterion 20 per changes $20 \mathrm{a}$ and $20 \mathrm{~b}$. 


\subsubsection{Protection System Reliability and Testability}

a. Statement of Text

Criterion 21 - Protection system reliability and testability. The protection system shall be designed for high functional reliability and inservice testability commensurate with the safety functions to be performed. Redundancy and independence designed into the protection system shall be sufficient to assure that (1) no single fallure results in loss of the protection function and (2) removal from service of any component or channel does not result in loss of the required minimum redundancy unless the acceptable reliability of operation of the protection system can be otherwise demonstrated. The protection system shall be designed to permit periodic testing of its functioning when the reactor is in operation, including a capability to test channels independently to determine failures and losses of redundancy that may have occurred.

b. Justification

No change is recommended because the present Appendix A criterion is sufficiently general to apply to HTGRs.

\subsubsection{Protection System Independence}

\section{a. Statement of Text}

Criterion 22 - Protection system independence. The protection system shall be designed to assure that the effects of natural phenomena, and of normal operating, maintenance, testing, and postulated accident conditions on redundant channels do not result in loss of the protection function, or shall be demonstrated to be acceptable on some other defined basis. 
Design techniques, such as functional diversity or diversity in component design and principles of operation, shall be used to the extent practical to prevent loss of the protection function.

b. Justification

No change is recommended because the Appendix A criterion is sufficiently general to apply to HTGRs.

\subsubsection{Protection System Failure Modes}

a. Statement of Text

Criterion 23 - Protection system failure modes. The protection system sha11 be designed to fall into a safe state or into a state demonstrated to be acceptable on some other defined basis of conditions such as disconnection of the system, loss of energy (e.g., electric power, instrument air), or postulated adverse environments (e.g., extreme heat or cold, fire, pressure, steam, water, and radiation) are experienced.

b. Justification

No change is recommended because the Appendix A criterion is sufficiently general to apply to HTGRs.

\subsubsection{Separation of Protection and Control Systems}

a. Statement of Text

Criterion 24 - Separation of protection and control systems. The protection system shall be separated from control systems to the extent that failure of any single control system component or channel, or failure or removal from service of any 
single protection system component or channel which is common to the control and protection systems leaves intact a system satisfying all reliability, redundancy, and independence requirements of the protection system. Interconnection of the protection and control systems shall be limited so as to assure that safety is not significantly impaired.

\section{b. Justification}

No change is recommended because the present Appendix A criterion is sufficiently general to apply to HTGRs.

\subsubsection{Protection System Requirements for Reactivity Control Malfunctions}

a. Statement of Text

Criterion 25 - Protection system requirements for reactivity control malfunctions. The protection system shall be designed to assure that specified acceptable [fuet-design timits] design limits for the fuel and primary coolant system boundary are not exceeded for any single malfunction of the reactivity control systems, such as accidental withdrawal (not ejection or dropout) of control rods.

\section{b. Justification}

Changes $25 \mathrm{a}$ and $25 \mathrm{~b}$ are made to be compatible with the changes in Criterion 20 to recognize that fuel design limits are generally not the most limiting for reactors of the HTGR type. Otherwise, the intent of Criterion 25 is sufficiently general to apply to HTGRs. 


\subsubsection{Reactivity Contro1 System Redundancy and Capability}

a. Statement of Text

Criterion 26 - Reactivity system redundancy and capability. Two independent reactivity control systems of different design principles shall be provided. One of the systems shall use control rods [preferabty-inetuding-a positive] $26 a$ employing a reliable means for inserting the rods. One system [and] sha11 be capable of reliably controlling reactivity $26 b, 26 c$ $26 \mathrm{~d}$ changes to assure that under conditions of normal operation, including anticipated operational occurrences, and with appropriate margin for malfunctions such as stuck rods, specified acceptable [fuet-design-timits] design limits for the fuel and primary coolant system boundary are not exceeded. [The-second] One reactivity control system shall be capable of reliably controlling the rate of reactivity changes resulting from planned, normal power changes (including xenon burnout) to assure acceptable fuel design limits are not exceeded. One of the systems shall be capable of holding the reactor core subcritical under cold conditions.

\section{b. Justification}

This criterion was rephrased to reflect design principles incorporated in gas-cooled reactors. The criterion as stated in Appendix A appears to be applicable to pressurized water reactors, which vary the concentration of dissolved neutron poison in the primary coolant as one means of reactivity control. Gas-cooled reactors, however, do not employ this technique but use one or more system(s) of neutron absorber rods for controlling reactivity changes and the rate of reactivity changes which occur during normal operation and power changes. In some designs, a single system of highly absorbent "black" control rods is employed for shutdown, power change initiation and control, core power distribution shaping, and reactivity shimming. In other designs, a "black rod" system 
is used for normal shutdown, reactor trip, and coarse-scale shimming or burnup adjustments, while an independent system of "grey rods" is employed to execute normal power changes, fine-scale reactivity shimming, and core power distribution shaping.

In addition to the control rod system(s), reactors of the HTGR type provide a reserve shutdown system which can effect reactor shutdown independently of the control rods. The reserve shutdown system does not use control rods but inserts many discrete pellets of neutron absorber into the core. Since this system has no provision for routine or rapid removal of the absorber pellets, it is intended only as a backup to the "black" control rod system.

Changes 26c, 26d, 26g, and $26 \mathrm{~h}$ reflect the above considerations. Changes $26 \mathrm{e}$ and $26 \mathrm{f}$ reflect the philosophy expressed earlier that fuel design limits are generally not the most limiting parameter for HTGRs whereas limits for portions of the primary coolant system boundary may be. Changes $26 \mathrm{a}$ and $26 \mathrm{~b}$ delete reference to "positive" means to avoid controversy over whether gravity meets the criterion.

\subsubsection{Combined Reactivity Control Systems Capability}

\section{a. Statement of Text}

Criterion 27 - Combined reactivity control systems capability. The reactivity control systems shall be designed to have a combined capability [5-in-eonjunetfon-with-poison addition-by-the-emergeney-eore-eooting-system;] of reliably controlling reactivity changes to assure that under postulated accident conditions and with appropriate margin for stuck rods the capability to cool the core is maintained. 
b. Justification

Change 27 a deletes reference to poison injection by the emergency core cooling system because it is not relevant to HTGR design. Otherwise, this criterion is sufficiently general to be applicable to HTGRs.

\subsubsection{Reactivity Limits}

a. Statement of Text

Criterion 28 - Reactivity limits. The reactivity control systems sha1l be designed with appropriate limits on the potential amount and rate of reactivity increase to assure that the effects of postulated reactivity accidents can neither (1) result in damage to the [reactor-eootant-pressure] primary coolant system boundary greater than limited local yielding nor (2) sufficiently disturb the core, its support structures or other reactor pressure vessel internals to impair significantly the capability to cool the core. These postulated reactivity accidents shall include consideration of rod ejection (unless prevented by positive means), rod dropout (unless prevented by positive means), [steam-tine-rupture;] rupture of steam or

$28 \mathrm{c}$ other secondary fluid line, changes in [reactor] primary coolant temperature, [and-pressure;-and-cołd-water-additionst] and ingress of secondary or other fluids.
$28 \mathrm{~d}, 28 \mathrm{e}$ $28 \mathrm{f}, 28 \mathrm{~g}$ $28 \mathrm{~h}$ $28 \mathrm{i}$

\section{b. Justification}

Changes $28 \mathrm{a}, 28 \mathrm{~b}, 28 \mathrm{f}$, and $28 \mathrm{~g}$ reflect differences in terminology, as discussed in Section 2.3.2.6.b. The addition numbered $28 \mathrm{c}$ reflects the impossibility of a rod dropout from HTGRs. The rods are actuated from above; they move in cylindrical holes in the core that are open at the top and closed at the bottom, thereby providing a positive mechanical stop that prevents rods dropping out of the core. However, postulated reactivity accidents may include "rod drops" within the confinement of the core. 
Change $28 \mathrm{~d}$ is made to reflect the fact that the direct-cycle HTGR configuration does not employ steam lines but does have secondary water lines. Furthermore, rupture of feedwater lines, as well as steam lines in a steam-cycle HTGR plant, could result in overcooling of the core with consequent reactivity addition. Change $28 \mathrm{~h}$ reflects the fact that the primary coolant in HTGRs is helium. This gas is much too low in density to serve as a moderator, except at extremely high pressures--pressures considered to be well beyond the range of credibility in HTGRs, which is the reason for deleting pressure considerations as a part of change $28 \mathrm{~h}$. Change $28 \mathrm{~h}$ also deletes reference to reactivity insertion by the thermal effect of adding cold water to the water coolant moderator. It is replaced by change $28 i$, which addresses the possibility of reactivity being added to the gas-cooled reactor by the ingress of fluids which are good neutron moderators.

\subsubsection{Protection Against Anticipated Operational Occurrences}

a. Statement of Text

Criterion 29 - Protection against anticipated operational occurrences. The protection and reactivity control systems shall be designed to assure an extremely high probability of accomplishing their safety functions in the event of anticipated operational occurrences.

b. Justification

No change is recommended because the Appendix A criterion is sufficiently general to apply to HTGRs. 
2.3.4. IV. Fluid Systems

2.3.4.1. Quality of Primary Coolant System Boundary

a. Statement of Text

Criterion 30 - Quality of [reactor-eootant-pressure] pri-

$30 \mathrm{a}, 30 \mathrm{~b}$

mary coolant system boundary. Components which are part of the

[reactor-eootant-system] primary coolant system boundary shall

$30 c, 30 d$

be designed, fabricated, erected, and tested to the highest

quality standards practical. Means shall be provided for

detecting and, to the extent practical, identifying the loca-

tion of the source of [reactor] primary coolant leakage.

b. Justification

Changes $30 \mathrm{a}$ through $30 \mathrm{f}$ are made to incorporate accepted terminology as presented in Sections 2.2.5 and 2.3.2.6. Otherwise, the statement of the criterion is unchanged.

\subsubsection{Fracture Prevention of Primary Coolant System Boundary}

a. Statement of Text

Criterion 31 - Fracture prevention of [reactor-eoołant

$31 \mathrm{a}$

pressure] primary coolant system boundary. The [reactor

$31 \mathrm{~b}, 31 \mathrm{c}$

cootant-pressure] primary coolant system boundary shall be

$31 \mathrm{~d}$ designed with sufficient margin to assure that when stressed under operating, maintenance, testing, and postulated accident conditions ( 1 ) the boundary behaves in a nonbrittle manner and (2) the probability of rapidly propagating fracture is minimized. The design shall reflect consideration of service temperatures and other conditions of the boundary material under 
operating, maintenance, testing, and postulated accident conditions and the uncertainties in determining (1) material properties, (2) the effects of irradiation on material properties, (3) residual, steady-state and transient stresses, and (4) size of flaws.

b. Justification

Changes $31 \mathrm{a}$ through $31 \mathrm{~d}$ reflect the appropriate terminology as defined in Section 2.2.5. No other changes are proposed.

\subsubsection{Inspection of Primary Coolant System Boundary}

a. Statement of Text

Criterion 32 - Inspection of [reactor-eootant-system] $32 a$ primary coolant system boundary. Components which are part of the [reactor-eootant-system] primary coolant system boundary shall be designed to permit (1) periodic inspection and testing of important areas and features [to-assess-their-strueturat $32 \mathrm{e}$ and] as appropriate to assess the structural integrity of pressure-bearing components or to assess leak-tight integrity, and (2) an appropriate material surveillance program [for-the reactor-pressure-vessetr]

\section{b. Justification}

Changes $32 \mathrm{a}$ through $32 \mathrm{~d}$ introduce terminology appropriate to the HTGR as defined in Sections 2.2.5 and 2.3.2.6. Changes $32 \mathrm{e}, 32 \mathrm{f}$, and $32 \mathrm{~g}$ are recommended in order to differentiate between requirements for pressure boundaries and coolant (gas) boundaries. Some components of the primary coolant system may be both a pressure boundary and a coolant boundary, as is the case for all components of a light-water reactor coolant pressure boundary. For such components, where a potential exists for a rapidly propagating failure, inservice inspection methods and frequencies 
compatible with ASME Codes are applied to reduce the likelihood of such failures. By contrast, the liner of the PCRV employed with the HTGR is not a pressure boundary but a leak-tight membrane. The pressure is borne by the concrete backing the liner. The liner is maintained in compression by the PCRV except, perhaps, for a few local areas and is designed to remain ductile throughout the plant life. Hence, the ASME Section XI, Division 2, Code requires that the shift in liner nil-ductility transition temperature be surveyed throughout the reactor life, but it does not require visual or volumetric inspection. Hence, changes $32 \mathrm{e}$ and $32 \mathrm{f}$ are introduced to permit flexibility in inspection requirements where warranted. Change $32 \mathrm{~g}$ deletes the phrase directed primarily to steel-walled reactor pressure vessels to generalize the surveillance requirement, as appropriate, to other components of the primary coolant system boundary, e.g., the PCRV liner.

\subsubsection{Reactor Coolant Makeup}

a. Statement of Text

$$
\text { [Eriterion-33---Reactor-eootant-makeup:--A-system-to }
$$

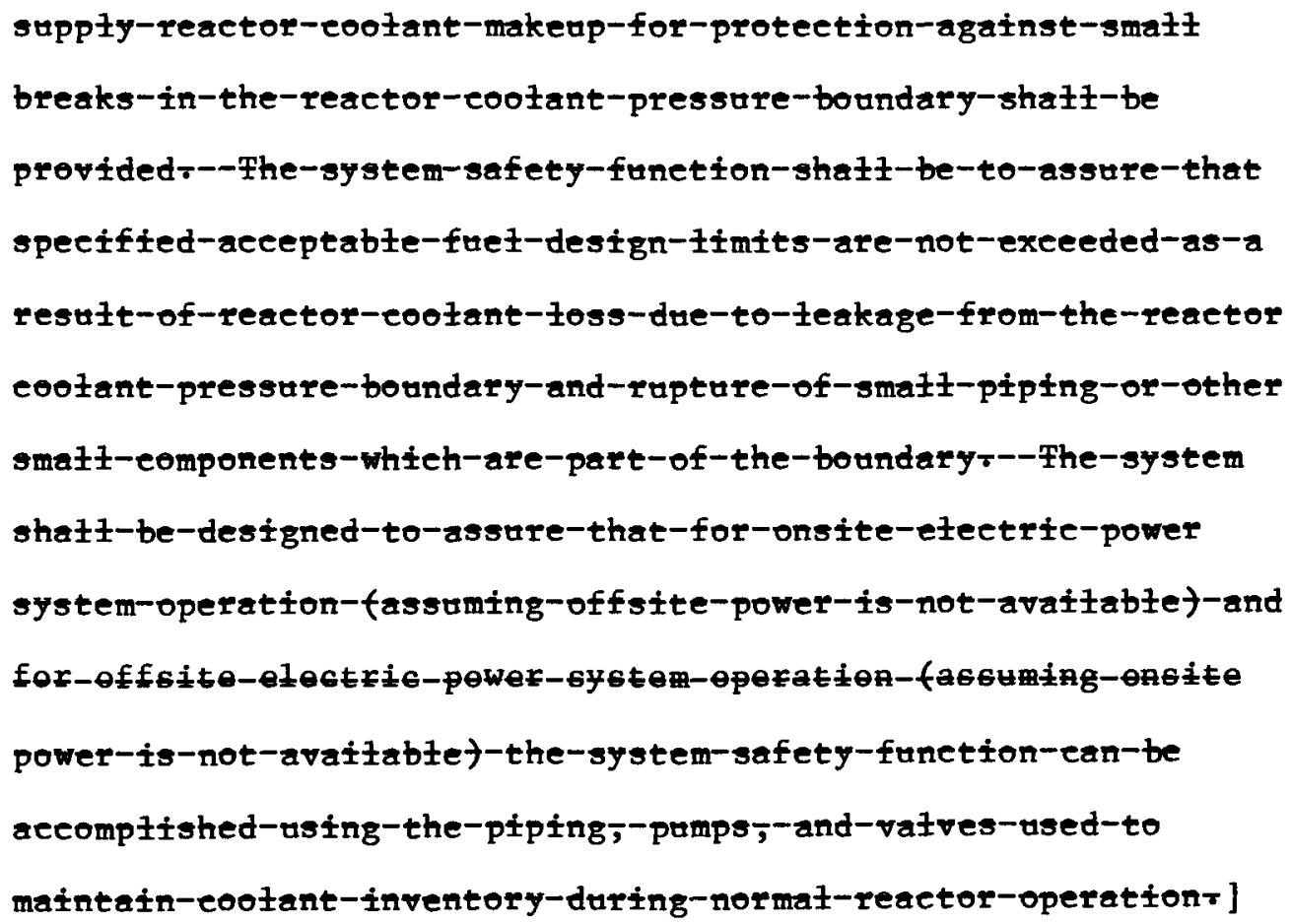




\section{b. Justification}

As discussed in Section 2.1, there is no need for supplemental or replacement coolant in HTGRs in the event that primary coolant leaks out of the reactor vessel as a result of small breaks in the primary coolant system boundary. The reason for this is that, in spite of reduction in primary coolant pressure as a result of such leaks, adequate core cooling can be maintained as long as the gaseous primary coolant can be circulated through the reactor core and the heat can be removed from the primary coolant. Thus, deletion $33 a$ is justified for HTGRs.

\subsubsection{Core Auxiliary Cooling System - I}

a. Statement of Text

Criterion 34 - [Residuat-heat-removat--A-system-to

Core auxiliary cooling system. A system shall be provided to remove fission product decay heat and other residual heat from the core at a rate such that specified acceptable limits of the fuel and other components within the primary coolant system boundary are not exceeded. The system, in conjunction with the protection, reactivity control, and cooling water systems, shall be capable of removing heat at a rate sufficient to prevent any damage which could inhibit effective core cooling following the loss of main loop cooling in conjuction with any anticipated operating occurrence or postulated accident including a design basis depressurization accident. 
Suitable redundancy in components and features, and suit-

able interconnections, leak detection, and isolation capabilities shall be provided to assure that for onsite electric power system operation (assuming offsite power is not available) and for offsite power system operation (assuming onsite power is not available) the system safety function can be accomplished, assuming a single failure.

b. Justification

Changes $34 \mathrm{a}$ and $34 \mathrm{~b}$ are recommended to delete the general functional requirement for a residual heat removal system and to replace it with the more specific requirements for the core auxiliary cooling system (CACS) employed in HTGR power plants.

The CACS provides decay heat removal for a spectrum of plant conditions. These conditions include the pressurized status when the primary coolant is at or near a pressure characteristic of the operating condition, and the depressurized status when the coolant is at low pressure such as that during refueling operations or after an accidental depressurization. The CACS, in conjuction with the cooling water system, serves as an engineered safeguard to provide core cooling whenever main loop cooling is lost. It also serves as a alternate cooling system during refueling if the main loops are down for maintenance. In the event of a design basis depressurization accident, defined in Section 2.2.6, the CACS maintains cooling with a mixture of primary coolant and containment atmospheric gas at equilibrium pressure.

It should be noted that the function and capability of the CACS, combined with the characteristics of the large heat capacity graphite core, preclude the need for Criterion 35 of Appendix A, which addresses an emergency core cooling system to provide the special requirements to prevent fuel and clad damage in a light-water reactor during a loss-of-coolant accident. 


\subsubsection{Core Auxiliary Cooling System - II}

a. Statement of Text

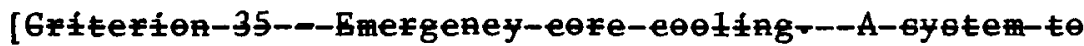

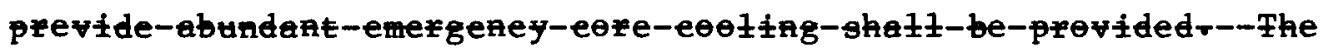

system-safety-funetion-shały-be-to-transfer-heat-from-the

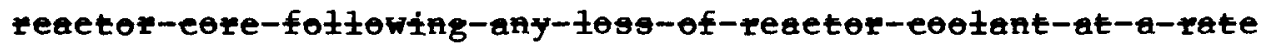

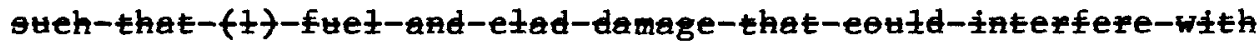

eontinted-effeetive-eore-eooting-is-prevented-and-fZt-eład

metal-water-zeaetion-is-1imited-to-negłigibłe-emetuter

Stitebłe-zedufdaney-in-eompeneqtg-and-featufes-and

suitabłe-tnterconnections;-łeak-deteetion;-isotation;-and

eontainment-eapabitities-shał $1-b e-p r o v i d e d-t o-a s s u r e-t h a t-f o r$

onsite-eteetric-power-system-operation-fassuming-offsite-power

Is-not-avaiłabłet-and-for-offsite-ełeetite-power-system

operation-fassuming-onsite-power-is-not-avatłabłet-the-system

safety-funetion-ean-be-aceompłtshed,-assuming-a-singłe

faiłurer]

b. Justification

Change 35a deletes this criterion because (1) the general intent to provide an engineered safety system for core cooling is achieved by the recommended Criterion 34 for the CACS, and (2) the specific requirements relating to fuel clad damage and metal-water reactions are not applicable to an HTGR. 


\subsubsection{Inspection of Core Auxiliary Cooling System}

a. Statement of Text

Criterion 36 - Inspection of [emergeney] core auxiliary

$36 a, 36 b$

cooling system. The [emergeney] core auxiliary cooling system

shall be designed to permit appropriate periodic inspection of

important components [such-as-spray-rings-in-the-reaetor

$36 \mathrm{e}$

pressure-vesset--water-injeetion-nozzłe--and-piping] to assure

the integrity and capability of the system.

\section{b. Justification}

Changes $36 \mathrm{a}$ through $36 \mathrm{~d}$ are made to support the modifications of Criterion 34 and deletion of Criterion 35 (Sections 2.3.4.5 and 2.3.4.6). Deletion $36 \mathrm{e}$ eliminates a reference to equipment that is unique to LWRs and not used in HTGRs.

\subsubsection{Testing of Core Auxiliary Cooling System}

a. Statement of Text

$$
\text { Criterion } 37 \text { - Testing of [emergeney] core auxiliary }
$$
cooling system. The [emergeney] core auxiliary cooling system shall be designed to permit appropriate periodic pressure and functional testing to assure (1) the structural and leak-tight integrity of its components, (2) the operability and performance of the active components of the system, and (3) the operability of the system as a whole and, under conditions as close to design as practical, the performance of the full operational sequence that brings the system into operation, including operation of applicable portions of the protection system, the transfer between normal and emergency power sources, and the operation of the associated cooling water system. 
b. Justification

Changes 37 a through $37 \mathrm{~d}$ are made to provide terminology to support Criterion 34 and deletion of Criterion 35.

\subsubsection{Containment Heat Removal System}

a. Statement of Text

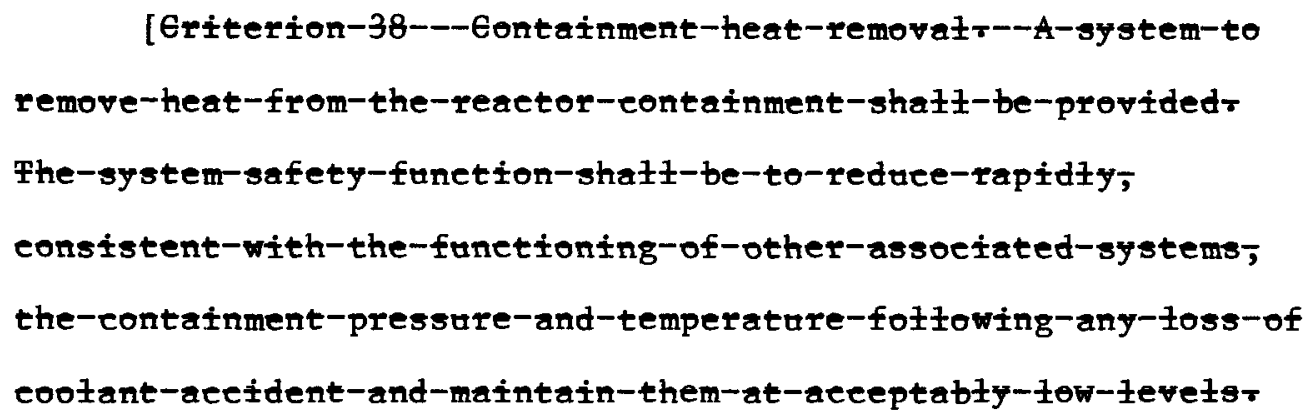

b. Justification

It is recommended that this criterion be deleted per change 38a because a containment heat removal system is not needed in HTGRs. Such heat removal systems are employed with light-water-cooled reactors because a loss of coolant accident (LOCA) releases a considerable amount of energy to the containment due to the large heat capacity of the reactor cooling water. By contrast, the helium coolant of HTGRs has low heat capacity, with the result that in the event of a design basis depressurization acci- 
dent, passive heat sinks afforded by structures and plant components within the containment remove heat at a fast enough rate to limit the containment atmosphere pressure and temperature to acceptably safe levels.

\subsubsection{Inspection of Containment Heat Remova1 System}

a. Statement of Text

[Eriterion-39---Inspection-of-containment-heat-removat system---The-containment-heat-removaz-system-shałz-be-designed to-permit-appropriate-periodie-inspeetion-of-important componets,-such-as-the-torus;-sumps--spray-nozxłes,-and-piping to-assure-the-integrity-and-eapabitity-of-the-systemr]

\section{b. Justification}

This criterion is deleted per change $39 \mathrm{a}$ to be compatible with the deletion of Criterion 38 in Section 2.3.4.9.

\subsubsection{Testing of Containment Heat Removal System}

a. Statement of Text

[Gxitexien-40---Testing-of-eontainment-heat-removat system---The-containment-heat-removal-system-shatz-be-designed to-permit-appropriate-periodte-pressure-and-funetionat-testing

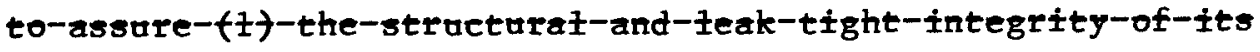
eomponents;- $(z)-$-the-operabttity-and-performance-of-the-aetive components-of-the-system--and- $(3)-t h e-o p e r a b i t i t y-o f-t h e-s y s t e m$ as-a-whele,-and,-under-conditiens-as-6lese-to-the-design-as practieat;-the-performance-of-the-futz-operationat-sequence that-brings-the-system-into-operation,-inetuding-operation-of 


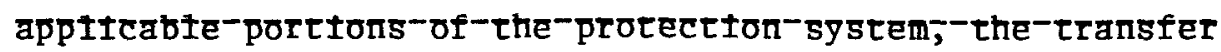

between-normał-and-emergeney-power-sources;-and-the-operation

of-the-assoeiated-eooting-water-systems ]

b. Justification

This criterion is deleted per change $40 \mathrm{a}$ to be compatible with the deletion of Criterion 38 in Section 2.3.4.9.

2.3.4.12. Containment Atmosphere Cleanup

a. Statement of Text

Criterion 41 - Containment atmosphere cleanup. Systems to control fission products [hydrogen;-oxygen,] and other substances which may be released to the containment shall be provided as necessary to reduce, consistent with the functioning of other associated systems, the concentration and quality of fission products released to the environment following postulated accidents and to control the concentration of [hydrogen or-oxygen-and-other-substanees] potentially flammable gaseous mixtures in the containment atmosphere following postulated accidents to assure that containment integrity is maintained.

Each system shall have suitable redundancy in components and features, and suitable interconnections, leak detection, isolation, and containment capabilities to assure that for onsite electric power system operation (assuming offsite power is not available) and for offsite electric power system operation (assuming onsite power is not available) its safety function can be accomplished, assuming a single failure. 


\section{b. Justification}

The portion of Criterion 41 of Appendix A that addresses control of fission product levels within containment is sufficiently general to be applicable to HTGRs. However, the requirement to control hydrogen concentrations stems from concern about the potential for generating a considerable quantity of gaseous hydrogen by metal-water reactions during the course of a loss-of-coolant accident in a light-water reactor plant. Therefore, changes $41 \mathrm{a}$ and $41 \mathrm{~b}$ are made to delete reference to such specific substances. The intent of the criterion is maintained by requiring control of "other substances . . . as necessary," and by requiring control of "potentially flammable gaseous mixtures" in change 41c. Although certain postulated events for an HTGR may generate potentially flammable gases, the design criteria for other systems, e.g. Criterion 14, which requires protection against ingress of contaminating fluids into the primary coolant, can be applied as a means of preventing the formation of flammable mixtures and to preclude the need for a containment cleanup system for this purpose.

\subsubsection{Inspection of Containment Atmosphere Cleanup Systems}

\section{a. Statement of Text}

Criterion 42 - Inspection of containment atmosphere cleanup systems. The containment atmosphere cleanup systems shall be designed to permit appropriate periodic inspection of important components, such as filter frames, ducts, and piping to assure the integrity and capability of the systems.

b. Justification

No change is recommended since the Appendix A criterion is sufficiently general to apply to HTGRs. 


\subsubsection{Testing of Containment Atmosphere Cleanup Systems}

a. Statement of Text

Criterion 43 - Testing of containment atmosphere cleanup systems. The containment atmosphere clearup systems shall be designed to permit appropriate periodic pressure and functional testing to assure (1) the structural and leak-tight integrity of its components, (2) the operability and performance of the active components of the systems such as fans, filters, dampers, pumps, and valves and (3) the operability of the systems as a whole and, under conditions as close to design as practical, the performance of the full operational sequence that brings the systems into operation, including operation of applicable portions of the protection system, the transfer between normal and emergency power sources, and the operation of associated systems.

\section{b. Justification}

No change is recommended since the Appendix A criterion is sufficiently general to apply to HTGRs.

\subsubsection{Cooling Water System}

a. Statement of Text

Criterion 44 - Cooling water. A system to transfer heat from structures, systems, and components important to safety, to an ultimate heat sink shall be provided. The system safety function shall be to transfer the combined heat load of these structures, systems, and components under normal operating and accident conditions. 
Suitable redundancy in components and features, and suitable interconnections, leak detection, and isolation capabilities shall be provided to assure that for onsite electric power system operation (assuming offsite power is not available) and for offsite electric power system operation (assuming onsite power is not available) the system safety function can be accomplished, assuming a single failure.

\section{b. Justification}

No change is recommended since the Appendix A criterion is sufficiently general to apply to HTGRs. Current designs for direct cycle, steam cycle, and process heat HTGRs include a cooling water system to transport heat from the core auxiliary cooling system.

\subsubsection{Inspection of Cooling Water System}

a. Statement of Text

Criterion 45 - Inspection of cooling water system. The cooling water system shall be designed to permit appropriate periodic inspection of important components, such as heat exchangers and piping, to assure the integrity and capability of the system.

b. Justification

No change is recommended since the Appendix A criterion is sufficiently general to apply to HTGRs. 


\subsubsection{Testing of Cooling Water System}

a. Statement of Text

Criterion 46 - Testing of cooling water system. The cooling water system shall be designed to permit appropriate periodic pressure and functional testing to assure (1) the structural and leak-tight integrity of its components, (2) the operability and the performance of the active components of the system, and (3) the operability of the system as a whole and, under conditions as close ot design as practical, the performance of the full operational sequence that brings the system into operation for reactor shutdown and for [łoss-of-eootant] $46 a$ design basis depressurization accidents, including operation of applicable portions of the protection system and the transfer between normal and emergency power sources.

b. Justification

The Appendix A criterion is sufficiently general to apply to HTGRs except for the changes in terminology indicated by changes $46 \mathrm{a}$ and $46 \mathrm{~b}$.

\subsubsection{Overpressure Protection of Primary Coolant System Boundary}

a. Statement of Text

$$
\text { Criterion } 47 \text { - Overpressure protection of primary coolant }
$$
system boundary. A pressure relief system shall be provided for the primary coolant which will prevent primary coolant pressure from exceeding appropriate design limits for the reactor vessel during postulated accidents. 
b. Justification

A11 reactor systems, including light-water reactors, incorporate some means for pressure relief of the primary coolant system as required by applicable industry codes. It would appear appropriate that the General Design Criteria explicitly specify the use of such a system. Since Appendix A does not present an applicable criterion, the above Criterion 47 (an unused number in Appendix A) is proposed for applicability to gascooled thermal reactors.

2.3.4.19. Prestressed Concrete Reactor Vesse1 Liner Cooling

a. Statement of Text

Criterion 48 - Prestressed concrete reactor vessel liner cooling. To help maintain the integrity of the primary coolant system boundary, a system shall be provided to cool the reactor vessel metallic liner and concrete in the vicinity of the liner in order to protect against temperature effects which cause degradation of structural material and to limit thermal stresses in the reactor vessel. Capability shall be provided to assure that adequate thermal control of critical portions of the reactor vessel liner, such as ducts to the core auxiliary cooling system, is maintained for any postulated accident such that cooling the core to a safe shutdown condition will not be impaired. Means for inspection and testing of the liner cooling system shall be provided as appropriate.

b. Justification

Concrete tends to lose strength and to creep more when it is exposed to elevated temperatures for extended periods of time. In addition, stresses induced by thermal gradients in the reactor vessel must be maintained within acceptable limits. Therefore, to help preserve the integrity of the reactor vessel and the primary coolant system boundary, a 
cooling system is employed to remove heat from the concrete near the interface with the metallic liner. The capacity of the cooling system depends on the heat load across the liner as determined by the amount of insulation provided between the hot primary helium and the liner. Generally, this insulation will be provided in the form of fixed thermal barrier assemblies. In some HTGR applications, however, alternatives could be employed such as providing a layer of cooler, flowing helium next to the primary side of the liner. Criterion 48 provides requirements for gas-cooled thermal reactor systems that supplement the more general Criterion 15, which governs primary coolant system design.

\subsubsection{Reactor Containment}

\subsubsection{Containment Design Basis}

a. Statement of Text

Criterion 50 - Containment design basis. The reactor containment structure, including access openings and penetrations, $50 a$ [and-the-eontainment-heat-removat-system] shall be designed so that the containment structure and its internal compartments can accommodate, without exceeding the design-allowable release or leakage rates and with sufficient margin, the calculated pressure and temperature conditions resulting from [any-łoss $50 \mathrm{~d}$ of-eootant] the limiting design basis accident. The margin sh11 reflect consideration of (1) the effects of potential energy sources which have not been included in the determination of the peak conditions, [such-as-energy-in-steam-generators-and-energy-from-metal-water-and-other-ehemieat reactions-that-may-resutt-from-degraded-emergeney-core-cooting system-funetioning-] (2) the limited experience and experimental data available for defining accident phenomena and containment responses, and (3) the conservatism of the calculational model and input parameters. 
b. Justification

The overall intent of Criterion 50 is sufficiently general to apply to HTGRs. Change 50a merely adds the word "and" to be consistent with change $50 \mathrm{~b}$, which deletes reference to a containment heat removal system. Change $50 \mathrm{c}$ is made for compatibility with Criterion 16.

Change 50d deletes reference to the loss-of-coolant accident because it is not applicable to an HTGR; change 50e provides flexibility in defining the design basis event for the containment by allowing for the "limiting design basis accident" to be established and incorporated into the design requirements. Although the limiting containment design basis accident for HGTR plants that employ steam-cycle power conversion has been the "design basis depressurization accident," this may not hold for all HTGR applications and configurations. Change 50e allows for determination of the appropriate limiting event on a case-by-case basis, if necessary.

Change $50 \mathrm{f}$ also provides flexibility in applying the criterion to an HTGR by deleting reference to energy sources which are explicit to lightwater reactors or steam-cycle plants. By deleting these items, application of Criterion 50 in licensing proceedings would require that appropriate other "potential energy sources" be identified, if not already included in the limiting design basis accident.

\subsubsection{Fracture Prevention in Containment Structure}

\section{a. Statement of Text}

Criterion 51 - Fracture prevention [of-eontainment 51a pressure-boundary] in containment structure. The [reactor eontainment-boundary] containment structure shall be designed

with sufficient margin to assure that under operating, maintenance, testing, and postulated accident conditions (1) its ferritic materials behave in a nonbrittle manner and (2) the probability of rapidly propagating fracture that causes a 
violation of the design bases of Criterion 50 is minimized. The design shall reflect consideration of service temperatures and other conditions of the containment [boundary] structural

materials during operation, maintenance, testing, and postu-

lated accident conditions, and the uncertainties in determining

(1) material properties, (2) residual, steady-state, and

transient stresses, and (3) size of flaws.

b. Justification

The wording changes numbered $51 \mathrm{a}$ through $51 \mathrm{~d}$ and $51 \mathrm{f}$ are made for compatibility with Criterion 50 . Change $51 \mathrm{~g}$ provides recognition that some containment structures may be constructed from several different kinds of materials; this is in contrast with the simple steel containment (only one material) and with the steel-lined concrete containment in which the steel liner is the main consideration for achieving the goal of an essentially leak-tight containment boundary.

Change 5le is made to maintain the intent of Criterion 51 while remaining compatible with Criterion 50. A rapidly propagating fracture in a steel-lined containment would generally be undesirable since it would mean loss of the essentially leak-tight characteristic sought in a conventional containment. * However, it is recognized that the concrete structure of a containment can experience a rapidly propagating crack but that the reinforcing bars (rebar) or prestressing tendons tend to hold the crack closed, thereby minimizing the leakage through the crack. Irrespective of whether the containment is lined with steel or other approved material, the important consideration is not that a crack is formed through which leakage can occur, but that, should a crack occur, the resultant leakage would not cause a violation of the leakage and release provisions stipulated in Criterion 50.

${ }^{*}$ While this is undesirable, it may not be unacceptable if the resu1tant leakage rate is low enough that the requirements of Criterion 50 would not be violated. 


\subsubsection{Capability for Testing Controlled Releases and Leakage from Containment}

a. Statement of Text

Criterion 52 - Capability for [eontainment-Zeakage-rate

and leakage from containment. The containment and other equipment which may be subjected to containment test conditions shall be designed so that periodic integrated [teakage-rate] assure that leakage rates and releases can be controlled and maintained at or below design levels.

b. Justification

Changes $52 \mathrm{a}$ through $52 \mathrm{~d}$ are made to be consistent with Criteria 16 and 50. The emphasis with regard to the testing of the containment system is that radioactivity escaping from the containment (whether by leakage or controlled release) can be maintained within limits of acceptability established on the basis of doses and dose commitments that pose no undue risk to the health and safety of the public. Guidelines for levels of acceptable dose commitment are prescribed elsewhere in the Code of Federal Regulations, most notably in Part 100 of Title 10 and in Appendix I to Part 50 of Title 10.

\subsubsection{Provisions for Containment Testing and Inspection}

a. Statement of Text

Criterion 53 - Provisions for containment testing and inspection. The reactor containment shall be designed to permit (1) appropriate periodic inspection of all important areas, such as penetrations, (2) an appropriate surveillance 
program, and (3) periodic testing of the integrity of

b. Justification

Changes $53 \mathrm{a}$ and $53 \mathrm{~b}$ are made to be consistent with Criteria 50.

\subsubsection{Piping Systems Penetrating Containment}

a. Statement of Text

Criterion 54 - Piping systems penetrating containment. Piping systems penetrating [primary-reactor] containment shall be provided with leak detection, isolation, and containment capabilities having redundancy, reliability, and performance capabilities which reflect the importance to safety of isolating these piping systems. Such piping systems shall be designed with a capability to test periodically the operability of the isolation valves and associated apparatus and to determine if valve leakage is within acceptable limits.

b. Justification

The words "primary reactor" are deleted to avoid confusion with the prestressed concrete reactor vessel, which is sometimes called primary containment for HTGRs, and because of the implication of a secondary containment. 


\subsubsection{Primary Coolant System Boundary Penetrating Containment}

a. Statement of Text

Criterion 55 - [Reactor-eoołant-system] Primary coolant

$55 a, 55 b$

system boundary penetrating containment. Each line that is part of the [reaetor-eootant-pressure] primary coolant system

boundary and that penetrates [primary-reactor] containment

shall be provided with containment isolation valves as follows, unless it can be demonstrated that the containment isolation provisions for a specific class of lines, such as instrument lines, are acceptable on some other defined basis:

(1) One locked closed isolation valve inside and one locked closed isolation valve outside containment; or

(2) One automatic isolation valve inside and one locked closed isolation valve outside containment; or

(3) One locked closed isolation valve inside and one automatic isolation valve outside containment. A simple check valve may not be used as the automatic isolation valve outside containment; or

(4) One automatic isolation valve inside and one automatic isolation valve outside containment. A simple check valve may not be used as the automatic isolation valve outside containment.

Isolation valves outside containment shall be located as close to containment as practical and upon loss of actuating power, automatic isolation valves shall be designed to take the position that provides greater safety. 
Other appropriate requirements to minimize the probability or consequences of an accidental rupture of these lines or of lines connected to them shall be provided as necessary to assure adequate safety. Determination of the appropriateness of these requirements, such as higher quality in design, fabrication, and testing, additional provisions for inservice inspection, protection against more severe natura1 phenomena, and additional isolation valves and containment shall include consideration of the population density, use characteristics, and physical characterisitics of the site environs.

\section{b. Justification}

The intent of Criterion 55 is to be retained. The terminology changes 55a through 55d are discussed in Section 2.2.5 and 2.3.2.6. Change $55 \mathrm{e}$ is made for the reason stated in Section 2.3.5.5.b.

\subsubsection{Containment Isolation}

\section{a. Statement of Text}

Criterion 56 - [Primary] Containment isolation. Each line that connects directly to the containment atmosphere and penetrates [primary-reactor] containment shall be provided with containment isolation valves as follows, unless it can be demonstrated that the containment isolation provisions for a specific class of lines, such as instrument lines, are acceptable on some other defined basis:

(1) One locked closed isolation valve inside and one locked closed isolation valve outside containment; or

(2) One automatic isolation valve inside and one locked closed isolation valve outside containment; or 
(3) One locked closed isolation valve inside and one automatic isolation valve outside containment. A simple check valve may not be used as the automatic isolation valve outside containment; or

(4) One automatic isolation valve inside and one automatic isolation valve outside containment. A simple check valve may not be used as the automatic isolation valve outside containment.

Isolation valves outside containment shall be located as close to the containment as practical and upon loss of actuating power, automatic isolation valves shall be designed to take the position that provides greater safety.

b. Justification

The intent of Criterion 56 is retained. Changes $56 \mathrm{a}$ and $56 \mathrm{~b}$ are made for the reason stated in Section 2.3.5.5.b.

\subsubsection{Closed System Isolation Valves}

a. Statement of Text

Criterion 57 - Closed system isolation valves. Each line that penetrates [primary-reactor] containment and is neither

part of the [reactor-eoolant-pressure] primary coolant system boundary nor connects directly to the containment atmosphere shall have at least one containment isolation valve which shall be either automatic, or locked closed, or capable of remote manual operation. This valve shall be outside containment and located as close to the containment as practical. A simple check valve may not be used as the automatic isolation valve. 
b. Justification

The intent of Criterion 57 is retained. Change 57a is made for the reason stated in Section 2.3.5.5.b. Changes $57 \mathrm{~b}$ and $57 \mathrm{c}$ are made to be compatible with Section 2.2.5.

\subsubsection{Fuel and Radioactivity Control}

2.3.6.1. Control of Releases of Radioactive Materials to the Environment

a. Statement of Text

Criterion 60 - Control of releases of radioactive materials to the environment. The nuclear power unit design shall include means to control suitably the release of radioactive materials in gaseous and liquid effluents and to handle radioactive solid wastes produced during normal reactor operation, including anticipated operational occurrences. Sufficient holdup capacity shall be provided for retention of gaseous and liquid effluents containing radioactive materials, particularly where unfavorable site environmental conditions can be expected to impose unusual operational limitations upon the release of such effluents to the environment.

b. Justification

No change is recommended since the Appendix A criterion is sufficiently general to apply to HTGRs.

\subsubsection{Fuel Storage and Handling and Radioactivity Control}

a. Statement of Text

Criterion 61 - Fuel storage and handling and radioactivity control. The fuel storage and handling, radioactive 
waste, and other systems which may contain radioactivity shall be designed to assure adequate safety under normal and postulated accident conditions. These systems shall be designed ( 1 ) with a capability to permit appropriate periodic inspection and testing of components important to safety, (2) with suitable shielding for radiation protection, (3) with appropriate containment, confinement, and filtering systems, (4) with a residual heat removal capability having reliability and testability that reflects the importance to safety of decay heat and other residual heat removal, and (5) to prevent significant reduction in fuel storage coolant inventory under accident conditions.

\section{b. Justification}

No change is recommended since the Appendix A criterion is sufficiently general to apply to HTGRs.

\subsubsection{Prevention of Criticality in Fuel Storage and Handling}

a. Statement of Text

Criterion 62 - Prevention of criticality in fuel storage and handling. Criticality in the fuel storage and handling system shall be prevented by physical systems or processes, preferably by use of geometrically safe configurations.

\section{b. Justification}

No change is recommended since the Appendix A criterion is sufficiently general to apply to HTGRs. 


\subsubsection{Monitoring Fuel and Waste Storage}

a. Statement of Text

Criterion 63 - Monitoring fuel and waste storage. Appropriate systems shall be provided in fuel storage and radioactive waste systems and associated handling areas (1) to detect conditions that may result in loss of residual heat removal capability and excessive radiation levels and (2) to initiate appropriate safety actions.

\section{b. Justification}

No change is recommended since the Appendix A criterion is sufficiently general to apply to HTGRs.

\subsubsection{Monitoring Radioactivity Releases}

a. Statement of Text

Criterion 64 - Monitoring radioactivity releases. Means shall be provided for monitoring the reactor containment atmosphere, [spaces-containing-components-for-reeireutation-of-toss of-eootant-aceident-ftuids-] effluent discharge paths, and the plant environs for radioactivity that may be released from normal operations, including anticipated operational occurrences, and from postulated accidents.

\section{b. Justification}

The overall intent of Criterion 64 is sufficiently general to apply to HTGRs. Change 64a, however, deletes a requirement not applicable to gas-cooled reactors. Whereas a sump and a recirculation pumping system 
are provided in a water-cooled nuclear power plant to collect the fluids released as a result of loss-of-coolant accidents and recirculate these through the core, these are not required for a depressurization accident with an HTGR. First, the gas discharged into confinement tends to mix throughout the confinement atmosphere. Second, core cooling is maintained by circulating the gas remaining in the primary system by use of circulators which are part of the main or auxiliary cooling systems. No additional system(s) for the recirculation of this air-gas mixture is required. A system is provided for containment atmosphere cleanup (see Criterion 41).

REFERENCES

2-1. Arlotto, G.A., "General Design Criteria for HTGRs," NRC Office of Standards Development letter, April 18, 1975.

2-2. "HTGR Accident Initiation and Progression Analysis Status Report Phase II Risk Assessment," DOE Report GA-A15000, General Atomic Company, April 1978.

2-3. "Plan for Research to Improve the Safety of Light-Water Nuclear Power Plants," Nuclear Regulatory Commission Report NUREG-0438, Office of Nuclear Regulatory Research, April 12, 1978.

2-4. "Report to the American Physical Society by the Study Group on Light-Water Reactor Safety," supported by the National Science Foundation and the Atomic Energy Commission, April 28, 1975. 


\section{SUMMARY AND CONCLUSIONS}

A set of GDC for HTGRs are proposed in Section 2. These GDC, for the most part, comprise adaptations, interpretations, or direct application of the GDC established for U.S. commercial light-water-cooled reactors in Appendix A to Part 50, Title 10, of the Code of Federal Regulations. Although four of the Appendix A criteria are deleted because they pertain to phenomena unique to LWRs, two new criteria are introduced to address current design practices for HTGRs. The GDC proposed for HTGRs are intended to be applicable, by and large, to all types of thermal gascooled reactors including those which incorporate a secondary steam plant and steam driven turbine-generator, those which employ secondary coolant in process heat applications, and those which employ the primary coolant to drive a turbine generator in a direct cycle.

Where possible, because of the general nature or direct applicability to HTGRs, the Appendix A criteria were retained. In several instances, minor changes in terminology were made to improve applicability. For example, Appendix A criteria require that only fuel design limits not be exceeded; a similar requirement for primary coolant boundary design limits is added where appropriate to emphasize the fact that the ceramic fuel is generally not limiting in HTGRs. Similarly, references to a loss-of-coolant accident (LOCA) were generally changed to design basis depressurization accident (DBDA) since the latter is the phenomenon of interest for HTGRs. To reflect a need and current practice for HTGRs, criteria were added to reduce the likelihood and/or consequences of potential ingress of non-inert fluids into the primary coolant.

One change introduced through the proposed criteria is deletion of the requirement for an "essentially leak-tight" containment. This is viewed as a general update of Appendix A since it has been recognized in 
safety evaluations that relaxation of the requirement for a leak-tight containment may be required to allow use of proposed vented containments for light-water reactors to reduce the risk associated with certain accident scenarios. It seems appropriate that flexibility be introduced into the Appendix A criteria in the area of containment and containment isolation to allow consideration of a system that may yield controlled release of radioactivity of known amount as an improvement over a presumed leaktight system that may be induced to fail in certain accident sequences.

The two new criteria that are proposed address (1) the requirements for a liner cooling system for the PCRV, and (2) the requirements for a pressure relief system for the PCRV (actually, it appears that Appendix A should include an explicit requirement for primary coolant system pressure relief for all reactors).

It is believed that the set of GDC proposed herein for HTGRs will provide a better basis from which to design and license gas-cooled thermal reactors than the light-water-reactor-oriented criteria of Appendix A. 


\title{
APPENDIX X - GENERAL DESIGN CRITERIA FOR \\ HIGH-TEMPERATURE GAS-COOLED \\ NUCLEAR REACTOR PLANTS
}

\section{Table of Contents}

INTRODUCTION

DEF INITIONS

\author{
Nuclear Power Unit \\ Single Failure \\ Anticipated Operational Occurrences \\ Primary Coolant System Boundary \\ Design Basis Depressurization Accidents \\ Accidental Ingress of Secondary or Other Fluids
}

CRITERIA

I. Overa11 Requirements: Number

Quality Standards and Records . . . . . . . . . . . 1

Design Bases for Protection Against Natural Phenomena . . . . 2

Fire Protection .. . . . . . . . . . . . . . 3

Environmental and Missile Design Bases ........... 4

Sharing of Structures, Systems, and Components . . . . . 5

II. Protection by Multiple Fission Product Barriers:

Reactor Design . . . . . . . . . . . . . 10

Reactor Inherent Protection . . . . . . . . . . . . . 11

Suppression of Reactor Power Oscillations . . . . . . . . 12

Instrumentation and Control . . . . . . . . . . . 13

Primary Coolant System Boundary . . . . . . . . . . 14 
Primary Coolant System Design . . . . . . . . . . 15

Containment Design . . . . . . . . . . . . . . . . 16

Electric Power Systems . . . . . . . . . . . . . 17

Inspection and Testing of Electric Power Systems . . . . . 18

Control Room ..................... 19

III. Protection and Reactivity Control Systems:

Protection System Functions . . . . . . . . . . . . 20

Protection System Reliability and Testability . . . . . . . 21

Protection System Independence . . . . . . . . . . . . 22

Protection System Failure Modes . . . . . . . . . . . . 23

Separation of Protection and Control Systems . . . . . . . 24

Protection System Requirements for Reactivity Control

Malfunctions ................... 2 25

Reactivity Control System Redundancy and Capability . . . . 26

Combined Reactivity Control Systems Capability . . . . . . 27

Reactivity Limits . . . . . . . . . . . . . . 28

Protection Against Anticipated Operational Occurrences . . . 29

IV. Fluid Systems:

Quality of Primary Coolant System Boundary . . . . . . . 30

Fracture Prevention of Primary Coolant System Boundary . . . 31

Inspection of Primary Coolant System Boundary . . . . . . . 32

Core Auxilfary Cooling System . . . . . . . . . . . . 34

Inspection of Core Auxiliary Cooling System . . . . . . . 36

Testing of Core Auxiliary Cooling System . . . . . . . . 37

Containment Atmosphere Cleanup . . . . . . . . . . . 41

Inspection of Containment Atmosphere Cleanup Systems . . . . 42

Testing of Containment Atmosphere Cleanup Systems . . . . . 43

Cooling Water. . . . . . . . . . . . . . . 4 44

Inspection of Cooling Water System . . . . . . . . . 45

Testing of Cooling Water System . . . . . . . . . . . 46

Overpressure Protection of Primary Coolant System Boundary • 47

Prestressed Concrete Reactor Vessel Liner Cooling . . . . . 48

V. Reactor Containment:

Containment Design Basis . . . . . . . . . . . 50 
Fracture Prevention in Containment Structure. . . . . . .

Capability for Testing Controlled Releases and Leakage from

Containment . . . . . . . . . . . . . . . . . . .

Provisions for Containment Testing and Inspection . . . . . 53

Piping Systems Penetrating Containment . . . . . . . . . . 54

Primary Coolant System Boundary Penetrating Containment . . . 55

Containment Isolation . . . . . . . . . . . . . 56

Closed System Isolation Valves . . . . . . . . . . . 57

VI. Fuel and Radioactivity Control:

Control of Releases of Radioactive Materials to the

Fuel Storage and Handling and Radioactivity Control . . . . 61

Prevention of Criticality in Fuel Storage and Handling . . . . 62

Monitoring Fuel and Waste Storage . . . . . . . . . . 63

Monitoring Radioactivity Releases . . . . . . . . . . 64 


\section{INTRODUCTION}

Pursuant to the provisions of Para 50.34, an application for a construction permit must include the principal design criteria for a proposed facility. The principal design criteria establish the necessary design, fabrication, construction, testing, and performance requirements for structures, systems, and components important to safety; that is, structures, systems, and components that provide reasonable assurance that the facility can be operated without undue risk to the health and safety of the public.

These General Design Criteria establish minimum requirements for the principal design for graphite-moderated, high-temperature gas-cooled nuclear power plants similar in design and location to plants for which an operating license has been issued or licensing applications have been previously docketed by the Commission. The General Design Criteria are also considered to be generally applicable to other types of gas-cooled thermal-reactor nuclear power units such as those employing a direct-cycle gas turbine or those employed to produce process heat and are intended to provide guidance in establishing the principal design criteria for such other units.

The development of these General Design Criteria is not yet complete. For example, some of the definitions need further amplification. Also, some of the specific design requirements for structures, systems, and components important to safety have not as yet been suitably defined. Their omission does not relieve any applicant from considering these matters in the design of a specific facility and satisfying the necessary safety requirements. These matters include:

(1) Consideration of the need to design against single failures of passive components in fluid systems important to safety. (See Definition of Single Failure.) 
(2) Consideration of redundancy and diversity requirements for fluid systems important to safety. A "system" could consist of a number of subsystems each of which is separately capable of performing the specified system safety function. The minimum acceptable redundancy and diversity of subsystems and components within a subsystem, and the required interconnection and independence of the subsystems have not yet been developed or defined. (See Criteria 34, 41, and 44.)

(3) Consideration of the type, size, and orientation of possible breaks in components of the primary coolant system boundary in determining design requirements to suitably protect against postulated design basis depressurization accidents and ingress of secondary or other fluids into the primary system. (See Definitions of Design Basis Depressurization Accidents and Ingress of Secondary or Other Fluids.)

(4) Consideration of the possibility of systematic, nonrandom, concurrent failures of redundant elements in the design of protection systems and reactivity control systems. (See Criteria 22, 24, 26, and 29.)

(5) Consideration of factors that affect the availability of systems important to safety to perform their safety functions when called upon, for example, through the use of reliability assessment techniques such as fault trees and event trees.

It is expected that the criteria will be augmented and changed from time to time as important new requirements for these and other features are developed.

There will be some high-temperature gas-cooled nuclear plants for which the General Design Criteria are not sufficient and for which additional criteria must be identified and satisfied in the interest of public safety. In particular, it is possible that additional or different criteria may be needed to take into account unusual sites and environmental conditions and to provide for high-temperature gas-cooled nuclear power units of advanced design. Also, there may be high-temperature gas-cooled 
nuclear power units for which fulfillment of some of the General Design Criteria may not be necessary or appropriate. For plants such as these, departures from the General Design Criteria must be identified and justified.

DEFINITIONS AND EXPLANATIONS

Nuclear power unit. A nuclear power unit means a nuclear power reactor and associated equipment necessary for electric power generation or for supplying heat for industrial processes and includes those structures, systems, and components required to provide reasonable assurance the facility can be operated without undue risk to the health and safety of the public.

Single failure. A single failure means an occurrence which results in the loss of capability of a component to perform its intended safety functions. Multiple failures resulting from a single occurrence are considered to be a single failure. Fluid and electric systems are considered to be designed against an assumed single failure if neither (1) a single failure of any active component (assuming passive components function properly) nor (2) a single failure of a passive component (assuming active components function properly), results in a loss of the capability of the system to perform its safety functions. 1

Anticipated operational occurrences. Anticipated operational occurrences mean those conditions of normal operation which are expected to occur one or more times during the life of the nuclear power unit and include but are not limited to tripping of a helium circulator, helium circulator runup, tripping of a turbine generator set, isolation of the main condenser, and loss of all offsite power.

${ }^{1}$ Single failures of passive components in electric systems should be assumed in designing against a single failure. The conditions under which a single failure of a passive component in a fluid system should be considered in designing the system against a single failure are under development. 
Primary coolant system boundary. Primary coolant means the helium gas that flows through and transports heat away from the reactor core. Primary coolant system boundary means the physical structure that contains the primary coolant. For high-temperature gas-cooled reactors, the primary coolant system boundary consists of (1) the liner of the prestressed concrete reactor vessel ( $P C R V$ ) including cavity and penetration liners which are exposed to primary coolant, in conjuction with the prestressed concrete structure, (2) primary closures that seal penetrations in the liner of the PCRV, (3) system piping that contains primary coolant and penetrates the PCRV liner or closures up to and including the second isolation valve, (4) the PCRV overpressure protection system up to and including pressure relief valves that vent the containment, (5) system piping within the PCRV, such as heat exchanger tubing, that is exposed to primary coolant unless the boundary is provided external to the PCRV, and (6) primary coolant retaining parts of mechanical components such as seals on shafts of helium circulators or gas-turbines within the primary coolant system. In specific adaptations of the HTGR, it may be necessary to augment or modify this definition of primary coolant system boundary to proper1y address certain design features.

Design basis depressurization accidents. Design basis depressurization accidents mean those postulated accidents in which a rapid reduction in primary coolant pressure occurs as a result of egress of a portion of the primary coolant system inventory from a breach of the primary coolant system boundary up to a maximum credible flow area, e.g., a postulated failure of mechanical seals of rotating shafts which penetrate the primary coolant system boundary, or a postulated failure of the largest pipe, external to the PCRV, that is part of the primary coolant system boundary.

Accidental ingress of secondary or other fluids. An accidental ingress of secondary or other fluids is an event wherein a fluid such as water, steam, or other nonprimary fluid is inadvertently admitted to the primary coolant system. 
CRITERIA

I. Overa11 Requirements

Criterion 1 - Quality standards and records. Structures, systems, and components important to safety shall be designed, fabricated, erected, and tested to quality standards commensurate with the importance of the safety functions to be performed. Where generally recognized codes and standards are used, they shall be identified and evaluated to determine their applicability, adequacy, and sufficiency and shall be supplemented or modified as necessary to assure a quality product in keeping with the required safety function. A quality assurance program shall be established and implemented in order to provide adequate assurance that these structures, systems, and components will satisfctorily perform their safety functions. Appropriate records of the design, fabrication, erection, and testing of structures, systems, and components important to safety shall be maintained by or under the control of the nuclear power unit licensee throughout the life of the unit.

Criterion 2 - Design bases for protection against natural phenomena. Structures, systems, and components important to safety shall be designed to withstand the effects of natural phenomena such as earthquakes, tornadoes, hurricanes, floods, tsunami, and seiches without loss of capability to perform their safety functions. The design bases for these structures, systems, and components shall reflect: (1) Appropriate consideration of the most severe of the natural phenomena that have been historically reported for the site and surrounding area, with sufficient margin for the limited accuracy, quantity, and period of time in which the historical data have been accumulated; (2) appropriate combinations of the effects of normal and accident conditions with the effects of the natural phenomena and (3) the importance of the safety functions to be performed.

Criterion 3 - Fire protection. Structures, systems, and components important to safety shall be designed and located to minimize, consistent with other safety requirements, the probability and effect of fires and

$$
\text { A-8 }
$$


explosions. Noncombustible and heat resistant materials shall be used wherever practical throughout the unit, particularly in locations such as the containment and control room. Fire detection and fighting systems of appropriate capacity and capability shall be provided and designed to minimize the adverse effects of fires on structures, systems, and components important to safety. Firefighting systems shall be designed to assure that their rupture or inadvertent operation does not significantly impair the safety capability of these structures, systems, and components.

Criterion 4 - Environmental and missile design bases. Structures, systems, and components important to safety shall be designed to accommodate the effects of and to be compatible with the environmental conditions associated with normal operation, maintenance, testing, and postulated accidents, including design basis depressurization accidents. These structures, systems, and components shall be appropriately protected against dynamic effects, including the effects of missiles, pipe whipping, and discharging fluids, that may result from equipment failures and from events and conditions outside the nuclear power unit.

Criterion 5 - Sharing of structures, systems, and components. Structures, systems, and components important to safety shall not be shared among nuclear power units uless it can be shown that such sharing will not significantly impair their ability to perform their safety functions, including, in the event of an accident in one unit, an orderly shutdown and cooldown of the remaining units.

\section{Protection by Multiple Fission Product Barriers}

$$
\text { Criterion } 10 \text { - Reactor design. The reactor core and associated }
$$
coolant, control, and protection systems shall be designed with appropriate margin to assure that specified acceptable fuel design limits are not exceeded during any condition of normal operation including the effects of anticipated operational occurrences. 
Criterion 11 - Reactor inherent protection. The reactor core and associated coolant systems shall be designed so that in the power operating range the net effect of the prompt inherent nuclear feedback characteristics tends to compensate for a rapid increase in reactivity.

Criterion 12 - Suppression of reactor power oscillations. The reactor core and associated coolant, control, and protection systems shall be designed to assure that power oscillations which can result in conditions exceeding specified acceptable fuel design limits are not possible or can be reliably and readily detected and suppressed.

Criterion 13 - Instrumentation and control. Instrumentation shall be provided to monitor variables and systems over their anticipated ranges for normal operation, for anticipated operational occurrences, and for accident conditions as appropriate to assure adequate safety, including those variables and systems that can affect the fission process, the integrity of the reactor core, the primary coolant system boundary, and the containment and its associated systems. Appropriate controls shall be provided to maintain these variables and systems within prescribed operating ranges.

Criterion 14 - Primary coolant system boundary. The primary coolant system boundary shall be designed, fabricated, erected, and tested so as to have an extremely low probability of rapidly propagating failure, of gross rupture, and of abnormal leakage of (1) primary coolant to a secondary coolant or auxiliary coolant system, to the containment, or to the environment, and (2) secondary coolant or other fluids to the primary coolant system.

Criterion 15 - Primary coolant system design. The primary coolant system and associated auxiliary, control, and protection systems shall be desinged with sufficient margin to assure that the design conditions of the primary coolant system boundary are not exceeded during any condition of normal operation, including anticipated operational occurrences. 
Criterion 16 - Containment design. Reactor containment and associated systems shall be provided to establish a barrier against the uncontrolled release of radioactivity to the environment and to assure that the containment design conditions important to safety are not exceeded for as long as postulated accident conditions require. Containment design conditions important to safety include the siting criteria in Part 100 of Title 10 of the Code of Federal Regulations. During normal operating conditions, the containment and associated plant systems shall meet the release criteria in Appendix I to Part 50 of Title 10 of the Code of Federal Regulations.

Criterion 17 - Electric power systems. An onsite electric power system and an offsite electric power system shall be provided to permit functioning of structures, systems, and components important to safety. The safety function for each system (assuming the other system is not functioning) shall be to provide sufficient capacity and capability to assure that (1) specified acceptable fuel design limits and design conditions of the primary coolant system boundary are not exceeded as a result of anticipated operational occurrences and (2) the core is cooled and containment integrity and other vital functions are maintained in the event of postulated accidents.

The onsite electric power supplies, including the batteries, and the onsite electric distribution system, shall have sufficient independence, redundancy, and testability to perform their safety functions assuming a single failure.

Electric power from the transmission network to the onsite electric distribution system shall be supplied by two physically independent circuits (not necessarily on separate rights of way) designed and located so as to minimize to the extent practical the likelihood of their simultaneous failure under operating and postulated accident and environmental conditions. A switchyard common to both circuits is acceptable. Each of these circuits shall be designed to be available in sufficient time following a loss of all onsite alternating current power supplies and the other 
offsite electric power circuit, to assure that specified acceptable fuel design limits and design conditions of the primary coolant system boundary are not exceeded. One of these circuits shall be designed to be available in sufficient time following a design basis depressurization accident to assure that core cooling, containment integrity, and other vital safety functions are maintained.

Provisions shall be included to minimize the probability of losing electric power from any of the remaining supplies as a result of, or coincident with, the loss of power generated by the nuclear power unit, the loss of power from the transmission network, or the loss of power from the onsite electric power supplies.

Criterion 18 - Inspection and testing of electric power systems. Electric power systems important to safety shall be designed to permit appropriate periodic inspection and testing of important areas and features, such as wiring, insulation, connections, and switchboards, to assess the continuity of the systems and the condition of their components. The systems shall be designed with a capability to test periodically (1) the operability and functional performance of the components of the systems, such as onsite power sources, relays, switches, and buses, and (2) the operability of the systems as a whole and, under conditions as close to design as practical, the full operation sequence that brings the systems into operation, including operation of applicable portions of the protection system, and the transfer of power among the nuclear power unit, the offsite power system, and the onsite power system.

Criterion 19 - Control room. A control room shall be provided from which actions can be taken to operate the nuclear power unit safely under normal conditions and to maintain it in a safe condition under accident conditions, including design basis depressurization accidents. Adequate radiation protection shall be provided to permit access and occupancy of the control room under accident conditions without personnel receiving radiation exposures in excess of 5 rem whole body, or its equivalent to any part of the body, for the duration of the accident. 
Equipment at appropriate locations outside the control room shall be provided (1) with a design capability for prompt hot shutdown of the reactor, including necessary instrumentation and controls to maintain the unit in a safe condition during hot shutdown, and (2) with a potential capability for subsequent cold shutdown of the reactor through the use of suitable procedures.

III. Protection and Reactivity Control Systems

Criterion 20 - Protection system functions. The protection system shall be designed (1) to initiate automatically the operation of appropriate systems including the reactivity control systems to assure that specified acceptable design limits for the fuel and primary coolant system boundary are not exceeded as a result of anticipated operational occurrences and (2) to sense accident conditions and to initiate the operation of systems and components important to safety.

Criterion 21 - Protection system reliability and testability. The protection system shall be designed for high functional reliability and inservice testability commensurate with the safety functions to be performed. Redundancy and independence designed into the protection system shall be sufficient to assure that (1) no single failure results in loss of the protection function and (2) removal from service of any component or channel does not result in loss of the required minimum redundancy unless the acceptable reliability of operation of the protection system can be otherwise demonstrated. The protection system shall be designed to permit periodic testing of its functioning when the reactor is in operation, including a capability to test channels independently to determine failures and losses of redundancy that may have occurred.

Criterion 22 - Protection system independence. The protection system shall be designed to assure that the effects of natural phenomena, and of normal operating, maintenance, testing, and postulated accident conditions on redundant channels do not result in loss of the protection function, or shall be demonstrated to be acceptable on some other defined 
basis. Design techniques, such as functional diversity or diversity in component design and principles of operation, shall be used to the extent practical to prevent loss of the protection function.

Criterion 23 - Protection system failure modes. The protection system shall be designed to fall into a safe state or into a state demonstrated to be acceptable on some other defined basis of conditions such as disconnection of the system, loss of energy (e.g., electric power, instrument air), or postulated adverse environments (e.g., extreme heat or cold, fire, pressure, steam, water, and radiation) are experienced.

Criterion 24 - Separation of protection and control systems. The protection system shall be separated from control systems to the extent that failure of any single control system component or channel, or failure or removal from service of any single protection system component or channel which is common to the control and protection systems leaves intact a system satisfying all reliability, redundancy, and independence requirements of the protection system. Interconnection of the protection and control systems shall be limited so as to assure that safety is not significantly impaired.

Criterion 25 - Protection system requirements for reactivity control malfunctions. The protection system shall be designed to assure that specified acceptable design limits for the fuel and primary coolant system boundary are not exceeded for any single malfunction of the reactivity control systems, such as accidental withdrawal (not ejection or dropout) of control rods.

Criterion 26 - Reactivity system redundancy and capability. Two independent reactivity control systems of different design principles shall be provided. One of the systems shall use control rods employing a reliable means for inserting the rods. One system shall be capable of reliably controlling reactivity changes to assure that under conditions of normal operation, including anticipated operational occurrences, and with 
appropriate margin for malfunctions such as stuck rods, specified acceptable design limits for the fuel and primary coolant system boundary are not exceeded. One reactivity control system shall be capable of reliably controlling the rate of reactivity changes resulting from planned, normal power changes (including xenon burnout) to assure acceptable fuel design limits are not exceeded. One of the systems shall be capable of holding the reactor core subcritical under cold conditions.

Criterion 27 - Combined reactivity control systems capability. The reactivity control systems shall be designed to have a combined capability of reliably controlling reactivity changes to assure that under postulated accident conditions and with appropriate margin for stuck rods the capability to cool the core is maintained.

Criterion 28 - Reactivity limits. The reactivity control systems shall be designed with appropriate limits on the potential amount and rate of reactivity increase to assure that the effects of postulated reactivity accidents can neither (1) result in damage to the primary coolant system boundary greater than limited local yielding nor (2) sufficiently disturb the core, its support structures or other reactor pressure vessel internals to impair significantly the capability to cool the core. These postulated reactivity accidents shall include consideration of rod ejection (unless prevented by positive means), rod dropout (unless prevented by positive means), rupture of steam or other secondary fluid line, changes in primary coolant temperature, and ingress of secondary or other fluids.

Criterion 29 - Protection against anticipated operational occurrences. The protection and reactivity control systems shall be designed to assure an extremely high probability of accomplishing their safety functions in the event of anticipated operational occurrences. 
IV. Fluid Systems

Criterion 30 - Quality of primary coolant system boundary. Components which are part of the primary coolant system boundary shall be designed, fabricated, erected, and tested to the highest quality standards practical. Means shall be provided for detecting and, to the extent practical, identifying the location of the source of primary coolant leakage.

Criterion 31 - Fracture prevention of primary coolant system boundary. The primary coolant system boundary shall be designed with sufficient margin to assure that when stressed under operating, maintenance, testing, and postulated accident conditions (1) the boundary behaves in a nonbrittle manner and (2) the probability of rapidly propagating fracture is minimized. The design shall reflect consideration of service temperatures and other conditions of the boundary material under operating, maintenance, testing, and postulated accident conditions and the uncertainties in determining (1) material properties, (2) the effects of irradiation on material properties, (3) residual, steady-state and transient stresses, and (4) size of flaws.

Criterion 32 - Inspection of primary coolant system boundary. Components which are part of the primary coolant system boundary shall be designed to permit (1) periodic inspection and testing of important areas and features as appropriate to assess the structural integrity of pressurebearing components or to assess leak-tight integrity, and (2) an appropriate material surveillance program.

Criterion 34 - Core auxiliary cooling system. A system shall be provided to remove fission product decay heat and other residual heat from the core at a rate such that specified acceptable limits of the fuel and other components within the primary coolant system boundary are not exceeded. The system, in conjunction with the protection, reactivity control, and cooling water systems, shall be capable of removing heat at a rate sufficient to prevent any damage which could inhibit effective core cooling following the loss of main loop cooling in conjuction with any 
anticipated operating occurrence or postulated accident including a design basis depressurization accident.

Suitable redundancy in components and features, and suitable interconnections, leak detection, and isolation capabilities shall be provided to assure that for onsite electric power system operation (assuming offsite power is not available) and for offsite power system operation (assuming onsite power is not avaliable) the system safety function can be accomplished assuming a single failure.

Criterion 36 - Inspection of core auxiliary cooling system. The core auxiliary cooling system shall be designed to permit appropriate periodic inspection of important components to assure the integrity and capability of the system.

Criterion 37 - Testing of core auxiliary cooling system. The core auxiliary cooling system shall be designed to permit appropriate periodic pressure and functional testing to assure (1) the structural and leaktight integrity of its components, (2) the operability and performance of the active components of the system, and (3) the operability of the system as a whole and, under conditions as close to design as practical, the performance of the full operational sequence that brings the system into operation, including operation of applicable portions of the protection system, the transfer between normal and emergency power sources, and the operation of the associated cooling water system.

Criterion 41 - Containment atmosphere cleanup. Systems to control fission products and other substances which may be released to the containment shall be provided as necessary to reduce, consistent with the functioning of other associated systems, the concentration and quality of fission products released to the environment following postulated accidents and to control the concentration of potentially flammable gaseous mixtures in the containment atmosphere following postulated accidents to assure that containment integrity is maintained. 
Each system shall have suitable redundancy in components and features, and suitable interconnections, leak detection, isolation, and containment capabilities to assure that for onsite electric power system operation (assuming offsite power is not available) and for offsite electric power system operation (assuming onsite power is not available) its safety function can be accomplished assuming a single failure.

Criterion 42 - Inspection of containment atmosphere cleanup systems. The containment atmosphere cleanup systems shall be designed to permit appropriate periodic inspection of important components, such as filter frames, ducts, and piping to assure the integrity and capability of the systems.

Criterion 43 - Testing of containment atmosphere cleanup systems. The containment atmosphere cleanup systems shall be designed to permit appropriate periodic pressure and functional testing to assure (1) the structural and leak-tight integrity of its components, (2) the operability and performance of the active components of the systems such as fans, filters, dampers, pumps, and valves and (3) the operability of the systems as a whole and, under conditions as close to design as practical, the performance of the full operational sequence that brings the systems into operation, including operation of applicable portions of the protection system, the transfer between normal and emergency power sources, and the operation of associated systems.

Criterion 44 - Cooling water. A system to transfer heat from structures, systems, and components important to safety, to an ultimate heat sink shall be provided. The system safety function shall be to transfer the combined heat load of these structures, systems, and components under normal operating and accident conditions.

Suitable redundancy in components and features, and suitable interconnections, leak detection, and isolation capabilities shall be provided to assure that for onsite electric power system operation (assuming offsite power is not available) and for offsite electric power system operation 
(assuming onsite power is not available) the system safety function can be accomplished assuming a single failure.

Criterion 45 - Inspection of cooling water system. The cooling water system shall be designed to permit appropriate periodic inspection of important components, such as heat exchangers and piping, to assure the integrity and capability of the system.

Criterion 46 - Testing of cooling water system. The cooling water system shall be designed to permit appropriate periodic pressure and functional testing to assure (1) the structural and leak-tight integrity of its components, (2) the operability and the performance of the active components of the system, and (3) the operability of the system as a whole and, under conditions as close to design as practical, the performance of the full operational sequence that brings the system into operation for reactor shutdown and for design basis depressurization accidents, including operation of applicable portions of the protection system and the transfer between normal and emergency power sources.

Criterion 47 - Overpressure protection of primary coolant system boundary. A pressure relief system shall be provided for the primary coolant which will prevent primary coolant pressure from exceeding appropriate design limits for the reactor vessel during postulated accidents.

Criterion 48 - Prestressed concrete reactor vessel liner cooling. To help maintain the integrity of the primary coolant system boundary, a system shall be provided to cool the reactor vessel metallic liner and concrete in the vicinity of the liner in order to protect against temperature effects which cause degradation of structural material and to limit thermal stresses in the reactor vessel. Capability shall be provided to assure that adequate thermal control of critical portions of the reactor vessel liner, such as ducts to the core auxiliary cooling system, is maintained for any postulated accident such that cooling the core to a safe shutdown condition will not be impaired. Means for inspection and testing of the liner cooling system shall be provided as appropriate. 
V. Reactor Containment

Criterion 50 - Containment design basis. The reactor containment structure, including access openings and penetrations, shall be designed so that the containment structure and its internal compartments can accommodate, without exceeding the design-allowable release or leakage rates and with sufficient margin, the calculated pressure and temperature conditions resulting from the limiting design basis accident. The margin shall reflect consideration of (1) the effects of potential energy sources which have not been included in the determination of the peak conditions, (2) the limited experience and experimental data available for defining accident phenomena and containment responses, and (3) the conservatism of the calculational model and input parameters.

Criterion 51 - Fracture prevention in containment structure. The containment structure shall be designed with sufficient margin to assure that under operating, maintenance, testing, and postulated accident conditions (1) its ferritic materials behave in a nonbrittle manner and (2) the probability of rapidly propagating fracture that causes a violation of the design bases of Criterion 50 is minimized. The design shall reflect consideration of service temperatures and other conditions of the containment structural materials during operation, maintenance, testing, and postulated accident conditions, and the uncertainties in determining (1) material properties, (2) residual, steady-state, and transient stresses, and (3) size of flaws.

Criterion 52 - Capability for testing controlled releases and leakage from containment. The containment and other equipment which may be subjected to containment test conditions shall be designed so that periodic integrated testing can be conducted at containment design pressure to assure that leakage rates and releases can be controlled and maintained at or below design levels. 
Criterion 53 - Provisions for containment testing and inspection. The reactor containment shall be designed to permit (1) appropriate periodic inspection of all important areas, such as penetrations, (2) an appropriate surveillance program, and (3) periodic testing of the integrity of penetrations at containment design pressure.

Criterion 54 - Piping systems penetrating containment. Piping systems penetrating containment shall be provided with leak detection, isolation, and containment capabilities having redundancy, reliability, and performance capabilities which reflect the importance to safety of isolating these piping systems. Such piping systems shall be designed with a capability to test perfodically the operability of the isolation valves and associated apparatus and to determine if valve leakage is within acceptable limits.

Criterion 55 - Primary coolant system boundary penetrating containment. Each line that is part of the primary coolant system boundary and that penetrates containment shall be provided with containment isolation valves as follows, unless it can be demonstrated that the containment isolation provisions for a specific class of lines, such as instrument lines, are acceptable on some other defined basis:

(1) One locked closed isolation valve inside and one locked closed isolation valve outside containment; or

(2) One automatic isolation valve inside and one locked closed isolation valve outside containment; or

(3) One locked closed isolation valve inside and one automatic isolation valve outside containment. A simple check valve may not be used as the automatic isolation valve outside containment; or

(4) One automatic isolation valve inside and one automatic isolation valve outside containment. A simple check valve may not be used as the automatic isolation valve outside containment. 
Isolation valves outside containment shall be located as close to containment as practical and upon loss of actuating power, automatic isolation valves shall be designed to take the position that provides greater safety.

Other appropriate requirements to minimize the probability or consequences of an accidental rupture of these lines or of lines connected to them shall be provided as necessary to assure adequate safety. Determination of the appropriateness of these requirements, such as higher quality in design, fabrication, and testing, additional provisions for inservice inspection, protection against more severe natural phenomena, and additional isolation valves and containment shall include consideration of the population density, use characteristics, and physical characterisitics of the site environs.

Criterion 56 - Containment isolation. Each line that connects directly to the containment atmosphere and penetrates containment shall be provided with containment isolation valves as follows, unless it can be demonstrated that the containment isolation provisions for a specific class of lines, such as instrument lines, are acceptable on some other defined basis:

(1) One locked closed isolation valve inside and one locked closed isolation valve outside containment; or

(2) One automatic isolation valve inside and one locked closed isolation valve outside containment; or

(3) One locked closed isolation valve inside and one automatic isolation valve outside containment. A simple check valve may not be used as the automatic isolation valve outside containment; or 
(4) One automatic isolation valve inside and one automatic isolation valve outside containment. A simple check valve may not be used as the automatic isolation valve outside containment.

Isolation valves outside containment shall be located as close to the containment as practical and upon loss of actuating power, automatic isolation valves shall be designed to take the position that provides greater safety.

Criterion 57 - Closed system isolation valves. Each line that penetrates containment and is neither part of the primary coolant system boundary nor connects directly to the containment atmosphere shall have at least one containment isolation valve which shall be either automatic, or locked closed, or capable of remote manual operation. This valve shall be outside containment and located as close to the containment as practical. A simple check valve may not be used as the automatic isolation valve.

VI. Fuel and Radioactivity Control

Criterion 60 - Control of releases of radioactive materials to the environment. The nuclear power unit design shall include means to control suitably the release of radioactive materials in gaseous and liquid effluents and to handle radioactive solid wastes produced during normal reactor operation, including anticipated operational occurrences. Sufficient holdup capacity shall be provided for retention of gaseous and liquid effluents containing radioactive materials, particularly where unfavorable site environmental conditions can be expected to impose unusual operational limitations upon the release of such effluents to the environment.

Criterion 61 - Fuel storage and handling and radioactivity control. The fuel storage and handling, radioactive waste, and other systems which may contain radioactivity shall be designed to assure adequate safety under normal and postulated accident conditions. These systems shall be 
designed (1) with a capability to permit appropriate periodic inspection and testing of components important to safety, (2) with suitable shielding for radiation protection, (3) with appropriate containment, confinement, and filtering systems, (4) with a residual heat removal capability having reliability and testability that reflects the importance to safety of decay heat and other residual heat removal, and (5) to prevent significant reduction in fuel storage coolant inventory under accident conditions.

Criterion 62 - Prevention of criticality in fuel storage and handling. Criticality in the fuel storage and handling system shall be prevented by physical systems or processes, preferably by use of geometrically safe configurations.

Criterion 63 - Monitoring fuel and waste storage. Appropriate systems sha1l be provided in fuel storage and radioactive waste systems and associated handling areas (1) to detect conditions that may result in loss of residual heat removal capability and excessive radiation levels and (2) to initiate appropriate safety actions.

Criterion 64 - Monitoring radioactivity releases. Means shall be provided for monitoring the reactor containment atmosphere, effluent discharge paths, and the plant environs for radioactivity that may be released from normal operations, including anticipated operational occurrences, and from postulated accidents. 